\title{
Development and initial validation of a multidimensional questionnaire on the relationship to work (RWQ)
}

\author{
Geneviève Fournier $^{1}$ - Lise Lachance ${ }^{2}$ - Simon Viviers ${ }^{1} \cdot$ Imane Zineb Lahrizi $^{1}$. \\ Liette Goyer ${ }^{1}$. Jonas Masdonati ${ }^{3}$
}

Received: 8 February 2018 / Accepted: 29 April 2019

(c) Springer Nature B.V. 2019

\begin{abstract}
The paper presents first the theoretical foundations used to develop a pre-experimental version of a questionnaire on relationship to work, and then the four stages of its initial validation leading to an experimental version. These stages included: (1) Defining the dimensions and sub-dimensions of the relationship to work concept; (2) Operationalizing the dimensions and sub-dimensions and creating the items; (3) Verifying the face and content validity and developing the pre-experimental questionnaire; (4) Testing the pre-experimental questionnaire with 550 workers and 538 students, assessing its psychometric properties and elaborating the experimental questionnaire.
\end{abstract}

Keywords Relationship to work · Questionnaire development · Initial validation

\section{Résumé}

Développement et validation initiale d'un questionnaire multidimensionnel sur le rapport au travail (QRT). Cet article présente d'abord les fondements théoriques qui ont servi à élaborer une version pré-expérimentale d'un questionnaire sur le rapport au travail et présente ensuite les étapes de sa validation initiale qui a conduit à la création d'un questionnaire expérimental : 1) Définition conceptuelle des dimensions et des sous-dimensions du rapport au travail; 2) Opérationnalisation et élaboration des items; 3) Vérification de la validité apparente et de contenu et élaboration de la version pré-expérimentale du questionnaire; 4) Test du questionnaire pré-expérimen-

Geneviève Fournier

Genevieve.Fournier@fse.ulaval.ca

1 Centre de recherche et d'intervention sur l'éducation et la vie au travail, Pavillon des Sciences de l'Éducation, Université Laval, 2320, rue des Bibliothèques, Québec, QC G1V 0A6, Canada

2 Département d'éducation et pédagogie, Faculté des sciences de l'éducation, Université du Québec à Montréal, 405 Rue Sainte-Catherine Est, Montréal, QC H2L 2C4, Canada

3 Institut de psychologie, Quartier, UNIL-Mouline, Université de Lausanne, Bâtiment Géopolis, Bureau : 4116, 1015 Lausanne, Switzerland 
tal auprès de 550 travailleurs et 538 étudiants, analyse de ses qualités psychométriques et élaboration du questionnaire expérimental.

\section{Zusammenfasung}

Entwicklung und Erstvalidierung eines mehrdimensionalen Fragebogens zur Beziehung zur Arbeit (RWQ). In dem Beitrag werden zunächst die theoretischen Grundlagen zur Entwicklung einer Pretest Version eines Fragebogens zur Beziehung zur Arbeit und anschließend die vier Stufen der ersten Validierung, die zu einer experimentellen Version führen, vorgestellt. Diese Stufen umfassten: 1) Definieren der Dimensionen und Unterdimensionen des Konzepts Beziehung zur Arbeit; 2) Operationalisieren der Dimensionen und Unterdimensionen und bestimmen der Items; 3) Überprüfung der Augenscheins- und Inhaltsvalidität sowie Ausarbeitung des Pretest; 4) Erprobung des Pretests mit 550 Arbeitern und 538 Studenten, Beurteilung seiner psychometrischen Eigenschaften und Ausarbeitung des experimentellen Fragebogens.

\section{Resumen}

Desarrollo y validación inicial de un cuestionario multidimensional sobre la relación con el trabajo (RWQ). Inicialmente el documento presenta los fundamentos teóricos utilizados para desarrollar una versión pre-experimental de un cuestionario sobre la relación con el trabajo, y posteriormente las cuatro etapas de su validación inicial que conducen a una versión experimental. Estas etapas incluyen: 1) Definir las dimensiones y sub-dimensiones del concepto de relación con el trabajo; 2) Operacionalizar las dimensiones y sub-dimensiones y crear los ítems; 3) Verificar la validez del formato y del contenido y desarrollar el cuestionario pre-experimental; 4) Probar el cuestionario pre-experimental con 550 trabajadores y 538 estudiantes, evaluar sus propiedades psicométricas y elaborar el cuestionario experimental.

\section{Introduction}

Considerable changes in the labour market in the last 30 or 40 years have changed many workers' career paths (D’Amours, 2002; Kalleberg, 2009; Mercure, 2008, Pillon \& Vatin, 2003; Sennett, 2000; Sullivan \& Baruch, 2009). These paths, which have become more individualized and uncertain, are often marked by transitions, forks, periods of employment and unemployment, and a rather unpredictable sequence of jobs (Appay, 2001; Castel, 2006; Guilbert, Bernaud, Gouvernet, \& Rossier, 2016; Guillaume, 2009; Guillemard, 2004; Vultur \& Bernier, 2014). Numerous authors have since put forward the idea of a labour market divided into two parts: in the centre there are the permanent, the "indispensable," and the "protected" employees, and on the periphery, the atypical, precarious and the "contingent" (Gash, 2008; Mirvis \& Hall, 1996; Palmade, 2003; Rubery, 2006; Valenduc, Vendramin, Marcello, \& Mariangela, 2009). However, despite major changes that could lead a certain proportion of people to become increasingly disinterested in work, several studies around the world have shown that work is still an essential 
component in most people's lives (Duffy, Blustein, Diemer, \& Autin, 2016; Mercure \& Vultur, 2010; World Value Survey/WVS, 2008). Drawing its inspiration from MOW (1987) and Harpaz and Meshoulam (2004), this study focuses more specifically on people's relationship to work, understood here as a multidimensional construct in which each dimension reflects a particular facet of a person's connection and attachment to work in general and to his or her working life ${ }^{1}$.

In keeping with our goal to more precisely grasp and conceptually define the different dimensions of the relationship to work construct and to operationalize them, our team developed a research questionnaire and carried out an initial validation with a sample of over 500 workers and more than 500 students. This article presents the theoretical foundations on which the team developed the questionnaire, then reports on the different steps of its initial validation, and finally presents the experimental questionnaire resulting from the whole process.

\section{Conceptualizations and measurements of the relationship to work as a multidimensional construct}

The relationship to work, studied from the angle of the meaningful work, has attracted the attention of many researchers in the field of work psychology (e.g., Arnoux-Nicolas, Sovet, Lhotellier, Di Fabio, \& Bernaud, 2016; Dik, Byrne, \& Steger, 2013; Pattakos \& Dundon, 2017; Steger, Dik, \& Duffy, 2012). In these studies, the meaning of work would seem to be a multidimensional construct that, on the whole, refers to people's perceptions of what they do at work and the importance they attach to it (Wrzesniewski, Dutton, \& Debebe, 2003). Morin (2006), for example, breaks the concept down into three dimensions. The first, the meaning of work (sensus), refers to people's representations of work and the importance and value they attach to it. The second, work orientation (sumo), refers to what people look for in their work and the goals that guide their actions at work. Finally, the third dimension (phenomenology) refers to the coherence effect between the characteristics of day-to-day work and the expectations and values sought at work. Based on this conceptualization, this author constructed a scale measuring "meaningful work" (Morin, 2006). Arnoux-Nicolas et al. (2016) likewise identified three dimensions that make up the meaning of work, namely: the importance of work, that is, the meaning that people attribute to it; the direction, that is, what individuals can draw from work; and, finally, the contribution that the meaning of work makes to the meaning of life in general. These researchers developed a scale measuring the meaning of work based on these dimensions and validated it for France. Finally, Steger et al. (2012) also defined the direction of work with three dimensions: (1) greatergood motivation, (2) psychological meaningfulness in work, (3) meaning-making through work. These dimensions were operationalized in the Work and Meaning Inventory (WAMI).

\footnotetext{
1 This conception of the relationship to work is different from that of the relationship to a job, which refers more to one's link or attachment to one's job or employment (May, Gilson, \& Harter, 2004; Méda, 2015; Paugam, 2000).
} 
Despite their remarkable contribution to conceptualizing and evaluating the meaning of work, these studies do not address all the facets of the people's relationship to work and working life. For example, the question of the centrality of work in relation to other spheres of life, which appears to be fundamental in the appraisal of the relationship to work, is hardly present in these studies. What is more, many of them are primarily concerned with the meaning that people give to their work, job, and occupation (Judge, Weiss, Kammeyer-Mueller, \& Hulin, 2017; Morin \& Forrest, 2007; Weiss, 2002), which makes it difficult to grasp the relationship that people who are unemployed or in atypical employment situations (e.g., short-term contracts, temporary work, or self-employment) have with work. This, it would seem, points to the relevance of examining the conceptualization and operationalization of the relationship to work, a concept that comprises broader dimensions than those found in the meaning of work.

To date, few research tools have been developed to measure people's relationship to work while taking into account its multiple facets. To the best of our knowledge, the questionnaire developed by the MOW International Research Team (1987) is a pioneer in this regard. It was initially tested in eight countries-Belgium, England, Germany, Japan, Israel, the Netherlands, the United States, and Slovenia-and the structural stability of the theoretical model on which it is based has been confirmed in several studies (e.g., Harpaz \& Fu, 2002; Harpaz \& Meshoulam, 2004). The question underlying this team's work was formulated as follows: "What is the meaning of working life for human beings in modern society?" (p. 12). The model of the meaning of work is divided into five central dimensions and several sub-dimensions, namely: A. "Centrality of working as a life role," defined as "the general belief about the value of working in one's life." This dimension is split into two sub-dimensions: A.1 "Value orientation toward work as a life role" and A.2 "Decision orientation about preferred life spheres." These last two are also split into two more sub-dimensions: (A.1.a\&b) identification with work and involvement or commitment to working; (A.2.a\&b) identification based on a person's relative preference for life spheres and behaviour associated with preferred life spheres. B. "Societal norms about working," broken down into two general categories of norms, namely "entitlement work norms" and "obligation work norms." C. "Valued working outcomes," defined as the importance that people attribute to the expected results of their work (e.g., status and prestige). D. "Importance of work goals" defined as the importance attributed to each of the goals pursued in working life (e.g., job security). E. "Work-role identification," defined as the important roles that working plays in people's lives (e.g., product or service identification).

The tool proposed in 1987 by the team is indisputably the most comprehensive tool developed to date for measuring the relationship to work. It is, accordingly, one of the tools that has been most used up till now, be it in part or in full (e.g., Ardichvili, 2005, 2009; Harpaz \& Fu, 2002; Isaksson \& Johansson, 2000; Kuchinke, Kang, Oh, \& Kang, 2008; Manuti, 2006; Peterson \& Ruiz-Quintanilla, 2003; Sharabi \& Harpaz, 2010, 2011, 2013) and in highly varied cultural contexts (e.g., Harpaz, Honig, \& Coetsier, 2002; Kuchinke et al., 2011; Kuchinke \& Cornachione, 2010; Sharabi, 2011). However, given that occupational and living contexts have changed profoundly since the 1980s, it would seem that the 
operationalization of certain dimensions would gain from being reconsidered and other items would benefit from being reformulated or created in order to more accurately reflect the present-day reality workers must face. For example, the question of the absolute and relative centrality of work is solely measured on the basis of two questions, which makes it difficult to precisely assess the place of work in people's lives and the different ways they invest in this sphere of life. However, given the current state of the labour market and the ensuing diversity of career paths, we believe this issue to be complex and deserving of special attention.

Finally, Mercure and Vultur (2010) also looked at the issue of the relationship to work as a multidimensional construct. Drawing mainly on the questionnaire developed by the MOW team (1987), their study of more than 1000 respondents enabled them to define what they call work ethos, defined as "the set of values, attitudes, and beliefs relating to work that engender a way of living one's work in everyday life." The construct they developed is based on three dimensions. The first is the absolute and relative centrality of work. The absolute centrality of work refers to the degree to which work is important to people, regardless of its purposes. The relative centrality of work refers to the place that work occupies in relation to the other spheres of life and reflects the hierarchy of people's values. The second dimension concerns the purposes of work. Divided into two broad categories, economic and experiential, they reflect both the meaning that work takes on for people (meaning of work) and what they are looking for in that activity (ideal model of work). Finally, the third dimension refers to the attitudes towards the main managerial standards in play: moral prestige and moral commitment to the employer; investment of one's personal resources for work purposes, and adherence to the company's flexibility objectives. The construct developed by Mercure and Vultur (2010) is innovative and makes it possible to add important nuances to the conceptualization of the relationship that people now have with work. Nevertheless, despite the rich results of their study, there is as yet no tool for evaluating the developed construct.

In sum, with the exception of the tool developed by the MOW team in 1987, no tool has thus far been developed to evaluate the relationship to work as a multidimensional construct. In light of these observations, our team set itself the objective of developing such a tool so as to be able to take into account the new realities of work and people's contexts and, in so doing, to more precisely grasp the multiple aspects of their relationship to work. The development process took place in four stages. The first stage consisted in conceptually defining the dimensions and subdimensions of the relationship to work in order to establish which concepts and definitions associated with this relationship we would incorporate (e.g., Paullay, Alliger, \& Stone-Romero, 1994; Puplampu, 2009; Shea-Van Fossen \& Vredenburgh, 2014). The second stage consisted in operationalizing the dimensions and sub-dimensions and developing the items. The third stage involved verifying the face and content validity of the dimensions and sub-dimensions and the clarity of the items, as well as developing the pre-experimental version of the questionnaire. The fourth and final step was to test the pre-experimental questionnaire with two large samples (workers and students) and to assess some of its psychometric properties in order to develop the experimental version of the questionnaire. 


\section{Development and initial validation of a multidimensional questionnaire on the relationship to work (RWQ)}

The questionnaire's development was informed by integrating systemic (e.g., Patton \& McMahon, 2006; Pryor \& Bright, 2003; Vondracek \& Porfeli, 2008; Young \& Valach, 2008) and constructivist (e.g., Guichard, 2004, 2009; Peavy, 1993, 2004; Savickas, 2005) theories in career development and life course sociology (e.g., Elder, 2009; Gaudet, 2013; Heinz, Huinink, Swader, \& Weymann, 2009; Lalive d'Épinay, 2005; Sapin, Spini, \& Widmer, 2007). We also drew inspiration from David Blustein's work on labour (e.g., Blustein, 2006, 2011). This conceptual and integrated framework proposes four assumptions that have inspired the theoretical development and operationalization of the questionnaire's dimensions and sub-dimensions.

1. The relationship to work is built up along a biographical path, a life course. People's projects and actions must be evaluated in numerous contexts, including the occupational, social, and cultural contexts in which they occur. If workers are considered to have agency (Elder, Kirkpatrick Johnson, \& Crosnoe, 2003; Lent, 2005; Savickas et al., 2009; Vondracek \& Porfeli, 2008; Young \& Valach, 2004, 2008), the construction of their relationship to work takes place within social structures (e.g., organisation of work) and within numerous, diverse contexts (proximal and distal), which convey norms about work. These contexts change and vary in importance throughout one's career path and help to build one's relationship to work (Blustein, 2006; Loriol, 2017; Peterson, Krumboltz, \& Garmon, 2005).

2. A life course consists of several spheres or life trajectories in interaction and interdependence with each other, each one as part of a relational network (Blustein, 2011). The nature or strength of this interdependence varies at different points in the career path or stages in life. This interdependence can affect certain dimensions of the relationship to work, including the relative importance given to work in relation to other spheres of life (Crosnoe \& Elder, 2002; Guichard, 2013; Savickas et al., 2009).

3. Career paths and life courses are made up of stages, milestones, forks and transitions (Abbott, 2001; Bessin, Bidard, \& Grossetti, 2010; Deltand \& Kaddouri, 2014; Fournier et al., 2012) that can have a direct impact on people's commitments and priorities in life and on their overall expectations regarding their working lives. As a result, commitments in different spheres of life and expectations regarding one's working life are likely to change all throughout the biographical journey. They accordingly have a varying influence on the relationship to work.

4. The relationship to work is thus made up of dimensions that change less over time and that are less affected by circumstances and stages in life, and, contrastingly, other dimensions that are more affected (Harpaz \& Fu, 2002; Krumm, Grube, \& Hertel, 2013; Matthijs \& Kooij, 2011). 


\section{Stage 1: definition of dimensions and sub-dimensions}

This stage was based on two elements: (1) a review of the scientific literature that looked into the main dimensions generally associated with the relationship to work; and (2) data from individual semi-structured interviews conducted over the past 20 years by team members with various populations of workers (e.g., high-school, college, and university graduates working to enter the labour market; people aged 45 and over hoping to return the labour market). In all, seven dimensions were developed, defined, and operationalized.

\section{Dimension 1: the absolute centrality of work}

This dimension is defined as the general value given to work by people regardless of the other activities or roles in their lives (Harpaz \& Fu, 1997; Hattrup, Ghorpade, \& Lackritz, 2007; MOW, 1987; Pryor \& Davies, 1989) or as the degree of importance given by people to work in their lives, namely to what extent they consider it to be a central element in their lives (Erbès-Séguin, 1991; Hirschfeld \& Feild, 2000; Kanungo, 1982; Mannheim, 1975; Mannheim, Chomsky, \& Cohen, 1972; Walsh \& Gordon, 2008). This dimension can also be associated, at least in part, with the concept of "work meaningfulness" which was developed by Rosso, Dekas, and Wrzesniewski (2010) and defined as the amount of significance attached to work (pp. 94-95). Generally, studies tend to show that the higher the value or importance that people attribute to work and the more central it is to their lives, then the more they feel engaged in their role as a worker (Hattrup et al., 2007), the more it is a source of accomplishment, and the more it contributes to their identity and personal development (Arvey, Harpaz, \& Liao, 2004; Blustein, 2011; Méda \& Vendramin, 2013; Tziner, Ben-David, \& Sharoni, 2014). Likewise, numerous studies tend to show that the importance attached to work is a stable dimension in the relationship to work that does not vary greatly throughout a person's lifetime (Ardichvili, 2005; Bal \& Kooij, 2010; Harpaz \& Fu, 2002; Hirschfeld \& Feild, 2000; Kuchinke et al., 2011; Ruiz-Quintanilla, 1991; Samuel \& Harpaz, 2004; Saunders \& Nedelec, 2014).

In the questionnaire, the absolute centrality of work, which is considered to be a stable variable in the relationship to work, was conceptualized using two sub-dimensions, namely: the ideological value of work, defined as the individual's belief in the importance of work in human existence; and the existential value of work, defined as the importance of work in a person's life.

\section{Dimension 2: relative centrality of work and work valence}

The relative centrality of work generally refers to the relative value of work compared to the other activity spheres in people's lives (Ardchvili, 2009; Hirschfeld \& Feild, 2000; Mercure \& Vultur, 2010; Morin, 2006; Snir \& Harpaz, 2005) and the relative place that their role as a worker plays compared to their other life roles (Baker, Jacobs, \& Tickle-Degnen, 2003; Cook, 1994; Niles \& Goodnough, 1996; 
Parboteeah \& Cullen, 2003). It also refers to how much people identify with their work as compared to other activities (England, 1991; MOW, 1987) and their relative commitment to their role as a worker in comparison to other commitments in life (Sverko, Barbarovic, \& Sverko, 2008; Warr, 2008). The relative centrality of a worker's role is comprised of several dimensions, namely affective (commitment to the role), normative, behavioural (participation, i.e., energy, effort, and time invested in the role) and cognitive (knowledge gained from experience in a given role) (e.g., Langley, 1995; Super, 1981; Sverko et al., 2008). Several authors agree that the relative centrality of work may vary according to one's stage in life, changing priorities, and work contexts and life circumstances (Blustein, 2006, 2011; Coetsier \& Claes, 1985; Johansson \& Tham, 2006; Ruiz-Quintanilla \& Wilpert, 1991).

However, based on the interviews we conducted, and echoing what was also observed recently by Mercure and Vultur (2010) and Mercure and Dahan-Seltzer (2016), we noted that the link between a high relative centrality of work and a strong emotional commitment to work was not always as clear as many authors suggest (Sverko et al., 2008; Warr, 2008). Furthermore, when the relative centrality of work is secondary to other activities, it does not always seem to be associated with a lesser emotional commitment to work or with the perception that work contributes little to identity development. The nuances we found among the interviewed workers appeared to be primarily related to the way that they subjectively experienced work in general and to the extent to which their perception of this overall experience was positive or not. In other words, two individuals may consider that work and their role as workers take priority over their other activities and roles in life, but this relative centrality does not contribute in the same way to their relationship to work, depending on whether work in general is perceived and experienced positively or negatively. This perception of work, which we have called "work valence," is similar to the notion of "work meaning" developed by Rosso et al. (2010), which refers to what work signifies. It can be positive, negative, or neutral. We have thus hypothesized that the relative centrality of work, combined with the positive or negative valence accorded to work in general, is likely to result in a more precise analysis of the diverse ways in which people currently invest in work, as well as a more precise interpretation of their meanings and their contributions to people's relationship to work.

In the questionnaire, the dimension "relative centrality of work and work valence" is considered to be affected by life circumstances. It particularly depends on people's current or recent work experiences, the perceived stage in their career path, and their work and non-work contexts (Guichard, 2013; Patton \& McMahon, 2006; Peavy, 2004; Settersten, 2003).

The relative centrality of work and work valence was defined as the relative importance of work, the role as a worker in relation to other activities and roles in people's lives, and by the subjective weight of work in general.

Furthermore, the vast majority of national and international surveys show that work and family are generally the top two priorities in people's lives (as compared to leisure, community involvement, and religious activity), regardless of culture, gender, age, and job level (Borchert \& Landherr, 2009; Harding \& Hikspoors, 1995; Kuchinke, Cornachione, Oh, \& Kang, 2010). The recurrence of this result and its 
universal nature should encourage us to consider possible interpretations and, at the same time, to ask whether people really have a choice about making work a priority in their lives. In order to better understand the significance of the relative centrality of work in people's lives, our team felt it was important to explore and assess to what extent the expressed relative commitment to the work corresponded to what people actually desired. We thus created a sub-dimension entitled "Ideal involvement profile in the different activities and roles of life," which we defined as the hierarchy of life commitments that the people would want "if they had the choice."

\section{Dimension 3: purposes of work}

This dimension refers to the main goals or outcomes that people seek to achieve through work in general, the main values that they seek to actualize through work, and the approach that they take towards work (Ardichvili, 2009; Consiglio, Cenciotti, Bergogni, \& Schwartz, 2016; Duffy, 2010; MOW, 1987; Rosso et al., 2010). The numerous typologies developed for this dimension generally make a rather broad distinction between work purposes and values that are "expressive" (Harpaz \& Meshoulam, 2004; MOW, 1987; Sverko et al., 2008), "experiential" (Mercure \& Vultur, 2010), or "intrinsic" (Harpaz et al., 2002; Morin, 2006) versus those that are "instrumental," "economic," or "extrinsic" (MOW, 1987; Ros, Schwartz, \& Surkiss, 1999; Sverko et al., 2008). Overall, the first three are related to people's personal and social development, while the last three are concerned with ostensibly more utilitarian aspects. Moreover, a certain number of authors have recently observed that people simultaneously pursue goals in these two broad categories, suggesting that they may be interdependent (Cardador, 2009; Kuchinke et al., 2010; Loriol, 2017) and even difficult to distinguish (Chow, Krahn, \& Galambos, 2014; Hansen \& Leuty, 2012). For example, earning money can also be a considerable source of personal achievement. Studies show that people's most important values or goals are those on which they base their choices and decisions (Ruiz-Quintanilla, 1991; Wils, Luncasu, \& Waxin, 2007). Likewise, they play a decisive role in job satisfaction (Duffy \& Sedlacek, 2007; Super \& Sverko, 1995) and in work motivation (Mercure \& Vultur, 2010; Merriman, 2017; Roberson, 1990) and contribute considerably to the meaning given to work (Brief \& Nord, 1990; Rosso et al., 2010; Shea-Van Fossen \& Vredenburgh, 2014).

In light of the above, the dimension "purposes of work" is considered to be relatively independent of occupational and life circumstances and is linked to the people's value systems and aspirations (e.g., Mercure \& Vultur, 2010). It is to these enduring purposes that people refer in times of destabilization, change, and reorientation. This dimension has been defined as the stable, general, personal goals that people commonly pursue in their work. These purposes provide a partial account of what is important for people for this activity to make sense or be satisfactory. 


\section{Dimension 4: general expectations regarding working life}

To the best of our knowledge, general expectations regarding working life would appear to be less documented in the scientific literature, or, at the very least, are rarely treated separately from the purposes and values of work. The MOW (1987) team examined this notion of "working life" alongside the dimension "valued working outcomes" (e.g., status and prestige; social utility) and measured the importance that people attached to these values, based on several concrete characteristics of working life (Importance of work goals, e.g., job security; task variety). From a slightly different angle, Warr (2008) looked at people's work values and how they relate to the importance that they attach to their role as workers and to certain characteristics of work (e.g., good income; the possibility of meeting people). Finally, Morin and Forest (2007) defined the concept of "meaningful work" on the basis of 29 work characteristics (e.g., clear objectives; acknowledgement of skills).

Based on the above, we initially defined the dimension "general expectations regarding working life" as what is essential and a priority for people to find concrete examples of and draw from in their working lives in general. As previously suggested by the MOW team (1987), these expectations seemed to us to be linked to the purposes and values of work but they differ from them by being closer to the context of work and non-work life and to the concrete events experienced by people in their working lives. Based on our hypothesis, these expectations regarding working life are likely to change or be reassessed at important points in one's career path and life course.

Finally, inspired by the concept of coherence developed by Morin (2006) and Morin and Forest (2007) and so as to better understand people's general expectations regarding their working lives, we created a sub-dimension called "Meaningful working life." We defined it as the coherency between people's expectations regarding their working lives in general and their perception of what their working lives actually allow them to achieve. Accordingly, for each of the proposed expectations, the importance people attributed to it was measured as was their perception of being able to obtain it in their working lives.

\section{Dimensions 5, 6, and 7: mutual obligations and duties of employers, society, and workers and representations of decent work}

While distinct, the last three dimensions are complementary and refer to normative representations of work. They refer specifically to workers' perceptions of their obligations and duties, and to the elements constituting decent work.

\section{Dimension 5: obligations and duties of employers and society to workers}

While this dimension also appeared to be somewhat less present in the scientific literature on work, it nonetheless seemed to us to be central to the evaluation of one's relationship to work. Indeed, depending on the conceptual framework that is adopted, one's relationship to work is constructed in multiple social structures and cultural contexts which convey norms about work (Patton \& McMahon, 2006; Peterson et al., 2005; 
Settersten, 2003). According to MOW (1987) and Harpaz and Meshoulam (2004), these standards refer to the obligations and duties that organisations and society have towards workers. Drawing inspiration primarily from MOW (1987) and the work of Mercure and Vultur (2010), and secondarily from the literature on the psychological contract which deals with this issue in terms of reciprocal obligations and promises between employers and employees (Coyle-Shapiro \& Conway, 2004; Coyle-Shapiro \& Neuman, 2004; Guerrero, 2005; McDonald \& Makin, 2000; Rousseau, 1995; Turnley \& Feldman, 1998, 1999), this dimension was defined as people's representation of the obligations and duties that employers and society have towards workers.

\section{Dimension 6: obligations and duties of workers to employers and society}

Based on the same body of research as for the previous dimension, this dimension was defined as people's representations of workers' obligations and duties towards employers and society.

\section{Dimension 7: representations of decent work}

Decent work is the subject of much attention in the international research community (Blustein, Olle, Connors-Kellgren, \& Diamonti, 2016; Di Fabio \& Maree, 2016; Di Ruggiero, Cohen, Cole, \& Forman, 2015; Ribeiro, Silva, \& Figueiredo, 2016). A particular effort has been made to define universal criteria that would make it possible to determine guidelines (Anker, Chernyshev, Egger, Mehran, \& Ritter, 2003; Burchell, Sehnbruch, Piasna, \& Agloni, 2014; Duffy et al., 2017). These criteria have a normative character given that they refer to characteristics that are judged to be socially and culturally acceptable for work to be qualified as decent.

The criteria that are most often used to define decent work tend to converge and refer both to those dimensions related to working conditions (e.g., work that is chosen, unforced, and discrimination- and servitude-free; that provides an income that keeps people out of poverty) and to those dimensions more related to people's wellbeing at work (e.g., fair and equitable treatment that allows for work-family balance) (e.g., Anker et al., 2003; ILO, 1990). Duffy et al. (2017) recently employed the Psychology of Working Theory (PWT) (Duffy et al., 2016, p. 130) to develop a scale for decent work that measures workers' perceptions on the matter. The latter comprises five dimensions: (1) physical and interpersonally safe working conditions; (2) hours that allow for free time and adequate rest; (3) organizational values that complement family and social values; (4) adequate compensation, and (5) access to adequate health care.

To the best of our knowledge however, there is, as of yet, no scale that deals specifically with workers' own representations of what decent work is. That being said, these representations are also influenced by the labour norms that are embodied in our social structures and that likely contribute to people's relationship to work. As a complement to the two previous dimensions and based primarily on International Labour Organization (ILO) indicators, we consequently constructed a dimension to measure workers' representations of decent work. We defined decent work as that 
which provides people with sufficiently good working conditions and income to ensure their well-being, in which their skills are recognized, and in which they are treated with justice and dignity and with respect for their physical and psychological health.

\section{Stage 2: operationalization of dimensions and sub-dimensions: development of items}

This stage, which lasted 1 year, was carried out both on the basis of the scientific literature review presented above and, importantly, on the discourse of various populations of interviewed workers who were interviewed for research projects conducted during the past 20 years, including for example: young people aged 16-25 who were unemployed (e.g., Authors, 1994), graduates in the socio-professional integration phase (e.g., Fournier, \& Croteau, 1997; Masdonati et al., 2016), workers undergoing vocational retraining (e.g., Authors, submitted), workers of all ages in non-standard work (e.g., Bujold, Fournier, \& Lachance, 2013; Fournier, \& Bujold, 2005; Fournier et al., 2009; Fournier et al., 2011), and senior workers who were employed (e.g., Fournier et al., 2013) or not (e.g., Fournier et al., 2014). Finally, several existing scales and tools (e.g., Elizur, 1984; Gagné, Forest, Gilbert, Aubé, Morin, \& Maloni, 2010; Kanungo, 1982; MOW, 1987; Steger et al., 2012) were also considered during this stage.

The team first created a relatively high number of sub-dimensions and generated a very large number of items to ensure that each of the selected dimensions was covered as comprehensively as possible. In creating the items ${ }^{2}$ for the questionnaire as a whole, particular care was taken to capture the nuances found in the interviewed workers' answers so as to portray as accurately as possible their perception of their work situation and lives (e.g., Loriol, 2017). Finally, the team worked iteratively to refine the questionnaire, merging a few sub-dimensions whose definitions and items were too similar. At the end of this second stage, the questionnaire consisted of seven dimensions, 33 sub-dimensions, and 295 items, as shown in the following table.

\section{Stage 3: study of the face and content validity and development of the pre-experimental questionnaire, worker and student versions}

In order to evaluate the face and content validity, the questionnaire was submitted to a list of experts (21) from Brazil, Burkina Faso, Cameroon, Canada, France, Italy and Switzerland. These people were chosen because of their specializations in the field of work and psychometrics. Invited by e-mail to participate in the validity study of the questionnaire, 17 experts responded positively to the invitation and received, the following week, a link to the web page with the evaluation tool to be completed.

\footnotetext{
${ }^{2}$ Items have been designed in French.
} 
The tool consisted of an instruction sheet, as well as definitions of each dimension and sub-dimension and those of associated items. The experts were asked to assess the representativeness of items for each dimension and sub-dimension, the clarity of their wording (e.g., language level, choice of words) and the exhaustiveness with which they covered the dimension. At the end of each dimension, a space was reserved for comments and the addition of items. ${ }^{3}$

The main goal in analyzing the data collected from the experts was to calculate two indices associated with the items' representativeness and clarity, namely: interrater agreement (IRA), which measures the extent to which the experts share the same opinion in their assessment, and the content validity index (CVI), which measures the strength of the items' representativeness. A score greater than $80 \%$ was obtained for the IRA index and more than .90 for the CVI for the vast majority of items. These analyses led the team to eliminate 81 items, reword 38, and move one of them to another sub-dimension.

At the end of this stage, the pre-experimental version of the questionnaire consisted of 201 items divided into seven dimensions, each one with sub-dimensions (see Table 1). This version, which was initially intended for workers, was then adapted to suit a student population. Although the items are the same, the instructions have thus been slightly modified. Conjugated primarily in the future tense rather than in the present, the instructions ask the participants to indicate how they will view work and working life once they have entered or returned to the labour market (e.g., Here is a second set of statements that represent the value you personally plan to place on work in your life once you have entered or returned to the labour market). It should be noted finally that the sub-dimension "Meaningful working life" was excluded from the student version of the questionnaire.

\section{Stage 4: pre-experimentation and psychometric analyses of the questionnaire, worker and student versions}

The aim of this stage was to test the pre-experimental questionnaire with workers and students and to assess some of its psychometric properties in order to develop the experimental version of the questionnaire. Data collection was conducted through an online questionnaire using LimeSurvey software. An invitation by e-mail to answer the questionnaire anonymously was sent to the entire community of a large French-speaking Canadian university. The e-mail provided direct access to two versions of the questionnaire, one for workers and one for students. More specifically, the invitation was sent to 12,642 workers and 10,000 students of this university for a response rate of 3.95\% among workers and $5.38 \%$ among students. This response rate is comparable to that of other studies where recruitment was conducted out online (Manfreda, Berzelak, Vehovar, Bosnjak, \& Haas, 2008).

\footnotetext{
${ }^{3}$ A total of 1450 comments and suggestions were made by the experts and analyzed by the team.
} 


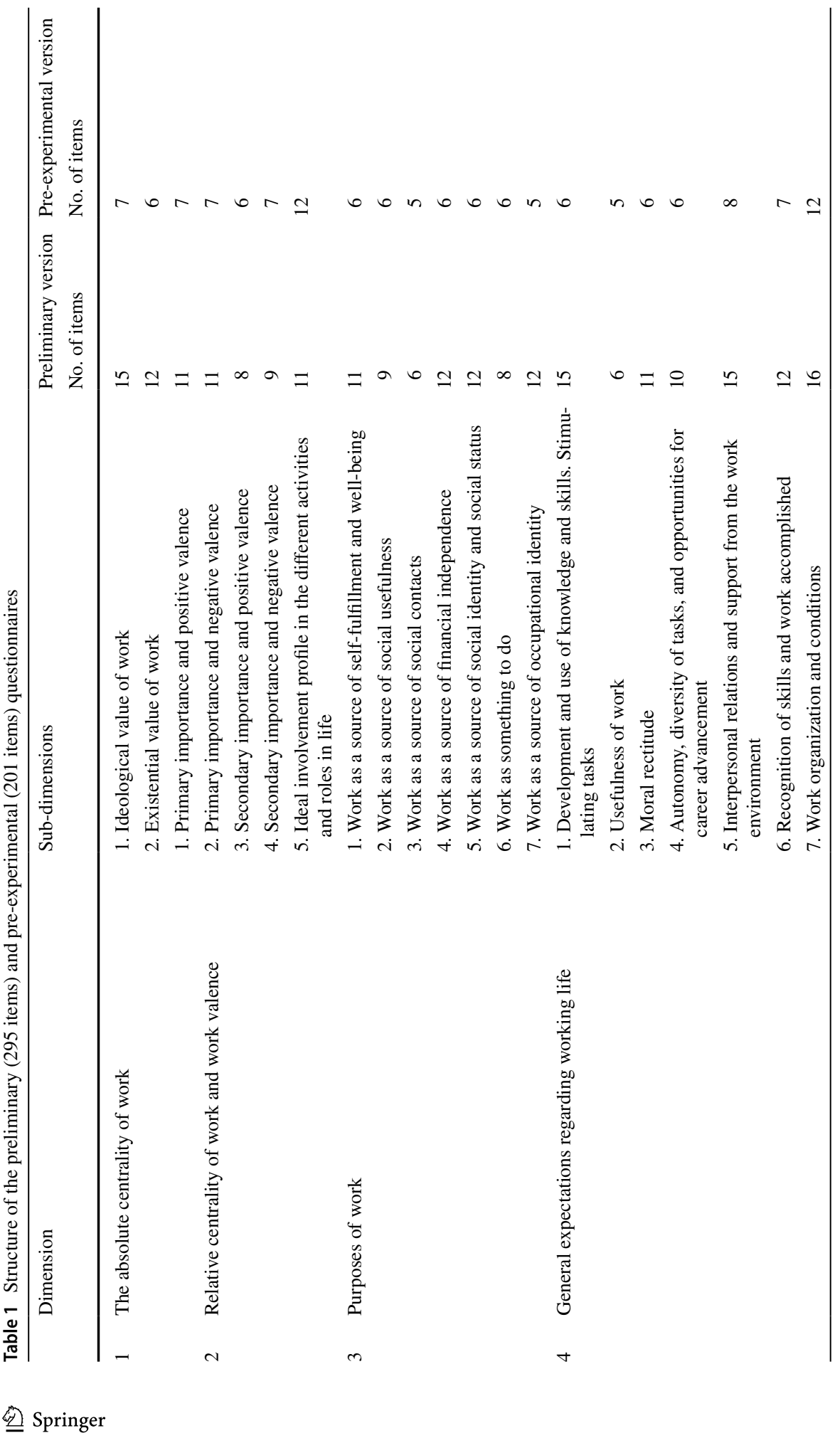




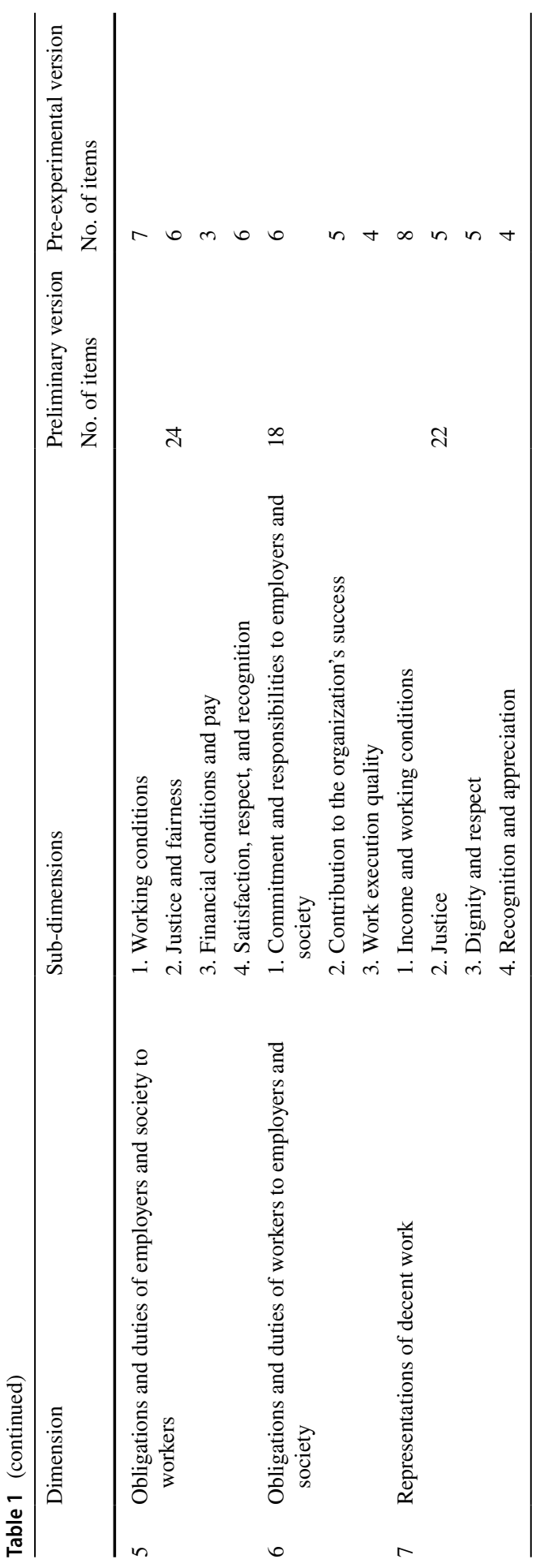




\section{Response scale}

A 5-point Likert scale was used for the whole questionnaire. For the first two dimensions (absolute centrality of work and relative centrality of work and work valence), the participants had to indicate their level of agreement with each item, on a scale going from 1 "do not at all agree" to 5 "completely agree". For the other dimensions, the participants indicated the level of importance accorded to each of the proposed items, on a scale going from 1 "not at all important" to 5 "very important."

\section{Participants}

Two distinct samples were formed for a total of 1088 participants.

\section{Workers}

The sample of 550 workers consisted of 179 men (36.5\%) and 311 women $(63.5 \%)$ aged 21 to $83(M=42.7$ years, $S D=11.8)$. Close to one-quarter $(n=119,24.6 \%)$ had a bachelor's degree and more than half $(n=259,53.5 \%)$ had a master's degree or Ph.D. Three-quarters $(n=368,76 \%)$ had a full-time job. The vast majority were born in Canada $(n=456,82.9 \%)$.

\section{Students}

The sample of 538 students was composed of 222 men (47.3\%) and 247 women $(52.7 \%)$ aged 18 to $54(M=25.7$ years, $S D=5.7)$. Recruited from all of the 17 faculties, more than half $(n=267,58.7 \%)$ were enrolled in the bachelor's program, $23.3 \%$ $(n=106)$ in the master's program, and 16\% $(n=73)$ in the Ph.D. program. Most of the participants $(n=421,92 \%)$ were registered full-time and slightly more than half $(n=244,53.3 \%)$ worked part-time.

\section{Analysis procedure}

The analysis was carried out independently and simultaneously on the data collected from students and workers. The analysis results obtained for the two subgroups were comparable. Thus, the results presented here concern only those obtained from workers. The analysis process consisted of four phases. The first examined item distribution through descriptive analyses (mean, standard deviation, skewness index, and kurtosis index). Twelve items with high skewness and kurtosis indices were removed (Bentler, 1983). The second phase consisted in verifying the factor structure of each dimension. This was accomplished by carrying out two analyses of the principal axis factoring with an orthogonal varimax rotation on each of the dimensions, one by retaining the factors whose eigenvalue was greater than 1 and the other by determining the number of factors according to what was conceptually expected. 
Prior to these analyses, Kaiser-Meyer-Olkin (KMO) coefficients were calculated in order to evaluate the extent to which the selected variables were consistent and to give an overview of the quality of the correlations between the items. The results showed that the KMO values for each dimension were greater than 0.7, which is considered satisfactory (Pett, Lackey, \& Sullivan, 2003). Moreover, particular attention was paid to the variance explained by the factors as well as to the communality of items and their factor loadings. Those with high loadings (greater than 0.4) on the factors with which they were conceptually associated and with low loadings on the other factors were retained. ${ }^{4}$ The purpose of the third phase was to evaluate the internal consistency of each of the sub-dimensions using Cronbach's alpha coefficients. The coefficient alpha values of the sub-dimensions were between 0.8 and 0.93 , with the exception of the following four sub-dimensions: "financial conditions and pay" ( $\alpha=0.77)$; "primary importance and negative valence" $(\alpha=0.75)$; "justice" $(\alpha=0.72)$; and "ideological value of work" $(\alpha=0.54)$. These results demonstrate a satisfactory internal consistency as they are greater than the required minimum threshold of 0.70 generally accepted in the scientific community (DeVellis, 2003; Hogan, 2007; Nunnally, 1978; Robinson, Shaver, \& Wrightsman, 1991; Towler \& Dipboye, 2003) and that of 0.80 in the case of the development of a research questionnaire (Nunnally \& Bernstein, 1994). It is worth noting that some items with lower factor loadings or a lower item-total correlation were reviewed and retained because of their conceptual importance. Finally, the goal of the fourth phase was to estimate the relations between the dimensions and sub-dimensions of the questionnaire in order to examine its construct validity. To do so, Pearson correlation coefficients were calculated.

\section{Results}

\section{Exploratory factor analyses for each dimension}

\section{Dimension 1: the absolute centrality of work}

Initially, this dimension consisted of 13 items and two sub-dimensions, namely ideological value of work and existential value of work (Table 2). The factor structure obtained here corresponded to the conceptual expectation $(49.6 \%$ explained variance). For each of the two sub-dimensions, the four items with a factor loading greater than .50 were selected. At the end of the process, this dimension consisted of eight items divided into two sub-dimensions: (1) ideological value of work (factor

\footnotetext{
${ }^{4}$ Here are some examples of items with lower factor loadings and that have been eliminated:.

«I never count my hours because I find work so enjoyable compared to my other activities » (Relative centrality of work and work valence)

«... give meaning to my life» (Purposes of work/Work as a source of self-fulfillment and well-being)

«... collaborate with other people» (Purposes of work/Work as a source of social contacts)

«... do work that respects my personal ethics » (General expectations regarding working life/Moral rectitude)
} 
Table 2 Factor structure for each of the dimensions, factor loadings for items selected for each subdimension, percentage of variance explained, and the internal consistency and means and standard deviation for each item $(n=550)$

The absolute centrality of work $(49.6 \%)$

Existential value of work $(\alpha=0.85)(29.8 \%)$

Factor 1.1

Without work, my life has no meaning $(\mathrm{M}=2.16 ; \mathrm{SD}=1.13)$

Without work, my life is not very interesting $(\mathrm{M}=2.38 ; \mathrm{SD}=1.19)$

My work defines me $(\mathrm{M}=2.5 ; \mathrm{SD}=1.11)$

Work is at the centre of my life $(\mathrm{M}=2.91 \mathrm{SD}=1.07)$

Ideological value of work $(\alpha=0.54)(19.8 \%)$

Factor 1.2

Work contributes to human dignity $(\mathrm{M}=3.88 ; \mathrm{SD}=0.96)$

.63

Human beings need work to find their place in society $(\mathrm{M}=3.56 ; \mathrm{SD}=1.09) \quad .60$

Work is at the heart of a well-functioning society $(M=3.42 ; \mathrm{SD}=0.81) \quad .60$

Work allows human beings to become the masters of their own lives $(\mathrm{M}=3.41 ; \mathrm{SD}=1.03)$

Relative centrality of work and work valence $(\mathbf{5 4 . 5 \% )}$

Primary importance and negative valence $(\alpha=0.75)$ Secondary importance and negative valence $(\alpha=0.89)(27.13 \%)$

In the overall scheme of my activities, work plays a secondary role and what I do there doesn't give me much satisfaction $(\mathrm{M}=1.47 ; \mathrm{SD}=0.87)$

Work is one of the lowest of my priorities and what I do there is of very little importance to me $(\mathrm{M}=1.3 ; \mathrm{SD}=0.70)$

Even though work plays a central role in relation to my other activities, what I'm doing does not satisfy me $(\mathrm{M}=1.51 ; \mathrm{SD}=0.89)$

Even though work plays a central role in relation to my other activities, it is still an unenjoyable activity $(\mathrm{M}=1.40 ; \mathrm{SD}=0.79)$

Even though my whole life is organized around work, what I do there is not very important to me $(\mathrm{M}=1.51 ; \mathrm{SD}=0.88)$

When compared to all the activities in my life, work plays a secondary role and I put the least amount of energy possible into it $(\mathrm{M}=1.48 ; \mathrm{SD}=0.78)$

Primary importance and positive valence $(\alpha=0.89)(17.24 \%)$

Factor 2.1

Work is the most important activity in my life. It's the one I devote the most energy to $(M=2.50$; $\mathrm{SD}=1.15)$

Work is my main activity in life and it brings me much more personal satisfaction than all my other activities $(\mathrm{M}=2.0 ; \mathrm{SD}=1.12)$

Work is the activity that defines me the most as a person because it's my highest priority $(\mathrm{M}=2.15 ; .80$ $\mathrm{SD}=1.14)$

Work plays a central role in my life and it is my favourite activity $(\mathrm{M}=2.31 ; \mathrm{SD}=1.03)$

Secondary importance and positive valence $(\alpha=0.81)(10.07 \%)$

Even though work plays a secondary role compared to my other activities, it still provides me with enriching experiences $(\mathrm{M}=3.76 ; \mathrm{SD}=1.11)$

Even though work plays a secondary role in relation to my other life activities, it helps to make me the person that $\mathrm{I}$ am $(\mathrm{M}=3.57 ; \mathrm{SD}=1.10)$

Even though work is not more important than my other activities, I get gratification from doing it $(\mathrm{M}=3.69 ; \mathrm{SD}=1.08)$

Even though work plays a secondary or similar role in relation to my other activities, I still need it to recharge my batteries $(\mathrm{M}=3.17 ; \mathrm{SD}=1.17)$

Purposes of work $(65.5 \%)$

Work as a source of social usefulness $(\alpha=0.93)(13.3 \%)$

Serve society $(\mathrm{M}=3.47 ; \mathrm{SD}=1.05)$

Help improve our society $(\mathrm{M}=3.42 ; \mathrm{SD}=1.06)$ 
Table 2 (continued)

Accomplish something important for society $(\mathrm{M}=3.55 ; \mathrm{SD}=1.07)$

Feel like I contribute to society $(\mathrm{M}=3.63 ; \mathrm{SD}=1.04)$

Play an active role in society $(\mathrm{M}=3.43 ; \mathrm{SD}=1.02)$

Work as a source of financial independence $(\alpha=0.91)(10.4 \%)$

Factor 3.2

Be financially independent $(\mathrm{M}=4.25 ; \mathrm{SD}=0.83)$

Feel financially secure $(\mathrm{M}=4.0 ; \mathrm{SD}=0.95)$

Be financially independent enough to achieve my main goals in life $(\mathrm{M}=4.29 ; \mathrm{SD}=0.8) \quad .79$

Meet my financial responsibilities $(\mathrm{M}=4.0 ; \mathrm{SD}=0.95)$

Work as a source of self-fulfillment and well-being $(\alpha=0.93)(9.6 \%)$

Be satisfied with myself $(M=4.17 ; \mathrm{SD}=0.85)$

Fulfil myself $(\mathrm{M}=4.07 ; \mathrm{SD}=0.93)$

Achieve my goals $(\mathrm{M}=4.13 ; \mathrm{SD}=0.92)$

Be proud of myself $(\mathrm{M}=4.11 ; \mathrm{SD}=0.88)$

Work as a source of social contacts $(\alpha=0.85)(9.5 \%)$

Factor 3.4

Create myself a social network $(\mathrm{M}=3.04 ; \mathrm{SD}=1.02)$

Make some friends $(\mathrm{M}=2.61 ; \mathrm{SD}=1.03)$

Have a social life $(\mathrm{M}=3.03 ; \mathrm{SD}=1.07)$

Meet people $(\mathrm{M}=3.32 ; \mathrm{SD}=1.02)$

Work as something to do $(\alpha=0.85)(9.1 \%)$

Factor 3.5

Do something with my time $(\mathrm{M}=2.62 ; \mathrm{SD}=1.16)$

Keep busy $(\mathrm{M}=2.96 ; \mathrm{SD}=1.16)$

Give structure to my days $(\mathrm{M}=2.66 ; \mathrm{SD}=1.12)$

Avoid boredom $(\mathrm{M}=2.71 ; \mathrm{SD}=1.33)$

Work as a source of occupational identity $(\alpha=0.83)(7.1 \%)$

Factor 3.6

Identify myself with people who are in the same occupation or profession as I am $(M=2.75$; $\mathrm{SD}=1.11)$

Be acknowledged by people who are in the same occupation or profession as I am $(M=2.99$; $\mathrm{SD}=1.1$ )

Feel that I belong to a group of workers who are in the same occupation or profession as I am $(\mathrm{M}=2.87 ; \mathrm{SD}=1.11)$

Master the skills of my occupation or profession $(\mathrm{M}=3.9 ; \mathrm{SD}=1.0)$

Work as a source of social identity and social status $(\alpha=0.85)(6.5 \%)$

Gain social prestige $(\mathrm{M}=2.64 ; \mathrm{SD}=1.02)$

Have a good social status $(\mathrm{M}=2.98 ; \mathrm{SD}=1.07)$

Have some social influence $(\mathrm{M}=2.73 ; \mathrm{SD}=1.06)$

General expectations regarding working life (55.4\%)

Development and use of knowledge and skills. Stimulating tasks $(\alpha=0.86)$ Moral rectitude $(\alpha=0.91)$ Work organization and conditions $(\alpha=0.86)(38.22 \%)$

Do something that is in keeping with who I am $(\mathrm{M}=4.33 ; \mathrm{SD}=0.8)$

Factor 4.1

Do my job while still respecting my principles $(\mathrm{M}=4.32 ; \mathrm{SD}=0.79)$

Do work in keeping with my values $(M=4.30 ; S D=0.79)$

Feel competent $(\mathrm{M}=4.49 ; \mathrm{SD}=0.68)$

Agree with what I am doing $(\mathrm{M}=4.5 ; \mathrm{SD}=0.69)$

Use my knowledge $(\mathrm{M}=4.42 ; \mathrm{SD}=0.69)$

Do work that I like $(\mathrm{M}=4.39 ; \mathrm{SD}=0.72)$ 
Table 2 (continued)

Have a work schedule that suits me $(M=4.43 ; S D=0.73)$

Maintain work-life balance $(\mathrm{M}=4.5 ; \mathrm{SD}=0.74)$

Earn a wage that matches my qualifications $(\mathrm{M}=4.32 ; \mathrm{SD}=0.77)$

Work organisation and conditions $(\alpha=0.86)$ (5.3\%)

Factor 4.2

Have social benefits (e.g., pension plan) $(\mathrm{M}=3.93$; $\mathrm{SD}=1.0)$

Have job security $(\mathrm{M}=4.04 ; \mathrm{SD}=1.0)$

Have a reasonable workload $(\mathrm{M}=3.93 ; \mathrm{SD}=0.83)$

.41

Interpersonal relations and support from the work environment $(\alpha=0.82)$ (4.2\%)

Factor 4.3

Work with people that I share common values with $(\mathrm{M}=3.94 ; \mathrm{SD}=0.96)$

Work with people with whom $\mathrm{I}$ have common interests $(\mathrm{M}=3.92 ; \mathrm{SD}=0.95)$

Be part of a team or group $(\mathrm{M}=3.71 ; \mathrm{SD}=1.07)$

.69

Develop friendships $(\mathrm{M}=3.25 ; \mathrm{SD}=1.09)$

Recognition of skills and work accomplished $(\alpha=0.89)(3.0 \%)$

Factor 4.4

Be recognized for the effort I put into my work $(M=4.15 ; \mathrm{SD}=0.83)$

.84

Receive positive comments about my work $(\mathrm{M}=4.07 ; \mathrm{SD}=0.86)$

Be recognized for the quality of my work $(\mathrm{M}=4.3 ; \mathrm{SD}=0.80)$

Get recognition from those who benefit from my work $(\mathrm{M}=3.98 ; \mathrm{SD}=0.93)$

.66

Autonomy, diversity of tasks, and opportunities for career advancement $(\alpha=0.84)(2.6 \%)$

Factor 4.5

Take part in decisions concerning how my work is organized $(\mathrm{M}=4.28 ; \mathrm{SD}=0.75)$

.81

Have a word to say about how my daily work is done $(\mathrm{M}=4.36 ; \mathrm{SD}=0.73)$

Participate in decisions concerning my career advancement $(\mathrm{M}=4.23 ; \mathrm{SD}=0.83)$

Take initiatives $(\mathrm{M}=4.19 ; \mathrm{SD}=0.84)$

Usefulness of work $(\alpha=0.84)(2.1 \%)$

Factor 4.6

Be of service to other people $(\mathrm{M}=4.0 ; \mathrm{SD}=0.93)$

Do work that makes people's lives easier $(\mathrm{M}=3.88 ; \mathrm{SD}=0.92) \quad .79$

Carry out tasks that are useful to others $(\mathrm{M}=4.18 ; \mathrm{SD}=0.81)$

Allow others benefit from my skills $(M=4.19 ; \mathrm{SD}=0.82)$

.66

Obligations and duties of employers and society to workers $(55.8 \%)$

Working conditions $(\alpha=0.82)$ Satisfaction, respect, and recognition $(\alpha=0.88)(27.2 \%)$

Ensure each person has a job that is important in his/her eyes $(M=3.61 ; \mathrm{SD}=1.04)$

Ensure each worker has the right conditions to progress in their career $(\mathrm{M}=3.83 ; \mathrm{SD}=1.94)$

Take into account each worker's opinion about how his/her work is organized and conducted $(\mathrm{M}=3.55 ; \mathrm{SD}=1.0)$

Ensure each person has a job that allows him/her to have a satisfying personal life $(\mathrm{M}=3.70$; $\mathrm{SD}=1.08$

Ensure each worker has the right to participate in training activities, whatever his/her status in the company or in the labour market $(\mathrm{M}=3.97 ; \mathrm{SD}=0.97)$

Ensure that each worker has a pension plan that will allow him/her to meet his/her main retirement needs $(\mathrm{M}=3.85 ; \mathrm{SD}=1.03)$

Ensure each worker has job security $(\mathrm{M}=3.55 ; \mathrm{SD}=0=1.12)$

Working conditions $(\alpha=0.82)$ Justice and fairness $(\alpha=0.83)$ Financial conditions and pay $(\alpha=0.77)(17.5 \%)$

Ensure each person, whatever his/her age, is treated fairly $(\mathrm{M}=4.54 ; \mathrm{SD}=0.73)$

Ensure each person has a work environment that is conducive to good mental health $(\mathrm{M}=4.55$; $\mathrm{SD}=0.66)$

Ensure each person works in a safe physical environment $(M=4.69 ; \mathrm{SD}=0.56)$ 
Table 2 (continued)

Financial conditions and pay $(\alpha=0.77)(11.3 \%)$

Ensure each person has a job that allows him/her to support him/herself $(M=4.15 ; S D=0.91)$

Ensure each person has a job that allows him/her to be financially independent $(\mathrm{M}=3.86 ; \mathrm{SD}=1.0) \quad .56$

\section{Obligations and duties of workers to employers and society $(58.7 \%)$}

Work execution quality ( $\alpha=0.89)(29.3 \%)$

Be trustworthy in the way he/she carries out his/her work $(\mathrm{M}=4.54 ; \mathrm{SD}=0.65)$

Carry out his/her work in a responsible manner $(\mathrm{M}=4.55 ; \mathrm{SD}=0.65)$

Do good quality work $(\mathrm{M}=4.53 ; \mathrm{SD}=0.61)$

When necessary, work with others to carry out tasks $(\mathrm{M}=4.31 ; \mathrm{SD}=0.73)$

Commitment and responsibilities to employers and society $(\alpha=0.8)(20.2 \%)$

Be loyal to his/her employer $(\mathrm{M}=3.74 ; \mathrm{SD}=1.09)$

Respect his/her employer $(\mathrm{M}=4.13 ; \mathrm{SD}=0.88)$

Defend his/her employer's image $(\mathrm{M}=3.39 ; \mathrm{SD}=1.04)$

Commitment and responsibilities to employers and society $(\alpha=0.8)(9.2 \%)$

Factor 6.3

Contribute to society by working $(\mathrm{M}=3.74 ; \mathrm{SD}=1.0)$

.68

Save part of his/her revenues to be independent at retirement $(\mathrm{M}=3.88 ; \mathrm{SD}=0.97)$

.49

Representations of decent work $(53.1 \%)$

Dignity and respect $(\alpha=0.81)(16 \%)$

In which workers are treated with dignity $(\mathrm{M}=4.70 ; \mathrm{SD}=0.59)$

In which the workers' psychological health is respected (e.g., no intimidation) $(M=4.65$; $\mathrm{SD}=0.61$

That ensures the workers' physical safety (e.g., excessive heat) $(\mathrm{M}=4.62 ; \mathrm{SD}=0.65)$

That respects the law $(\mathrm{M}=4.65 ; \mathrm{SD}=0.69)$

In which workers do not fear their bosses $(\mathrm{M}=4.24 ; \mathrm{SD}=0.83)$

.40

Recognition and appreciation $(\alpha=0.82)(14.1 \%)$

Factor 7.2

Where the workers' qualifications are recognized $(\mathrm{M}=4.06 ; \mathrm{SD}=0.84)$

In which workers can make decisions $(\mathrm{M}=3.49 ; \mathrm{SD}=1.0)$

In which workers can be promoted $(\mathrm{M}=3.46 ; \mathrm{SD}=1.05)$

Where the work corresponds to the workers' qualifications $(\mathrm{M}=3.94 ; \mathrm{SD}=0.89)$

Income and working conditions $(\alpha=0.82)(11.7 \%)$

That has job security $(\mathrm{M}=3.42 ; \mathrm{SD}=1.1)$

That has a regular pay $(\mathrm{M}=3.89 ; \mathrm{SD}=0.95)$

Where the work schedule is determined ahead of time $(\mathrm{M}=3.15 ; \mathrm{SD}=1.13)$

That guarantees that workers have social benefits (e.g., paid sick leave) $(\mathrm{M}=4.16 ; \mathrm{SD}=0.9)$

.56

Justice $(\alpha=0.72)(11.3 \%)$

.44

That protects workers from being arbitrarily fired $(\mathrm{M}=4.28 ; \mathrm{SD}=0.91)$

That protects workers from arbitrary, unfair actions $(M=4.15 ; \mathrm{SD}=0.94)$

In which the workers' right to collectively bargain is respected $(\mathrm{M}=3.91 ; \mathrm{SD}=1.12)$

The items that were removed do not appear in the table presenting the factor structure for each of the dimensions 
loadings from .53 to 0.63 ) and (2) existential value of work (factor loadings from .59 to .89).

\section{Dimension 2: relative centrality of work and work valence}

This dimension was originally comprised of 27 items and four sub-dimensions ${ }^{5}$ : (1) primary importance and positive valence; (2) primary importance and negative valence; (3) secondary importance and positive valence, and (4) secondary importance and negative valence. However, the factor structure revealed the presence of three factors that explain $54.5 \%$ of the variance. The first factor combined the two sub-dimensions that were conceptually associated with the negative valence of work, while the other two corresponded to the two sub-dimensions conceptually associated with the positive valence of work. For each of the latter sub-dimensions, four items were selected (factor loadings from .65 to .82). As regards the two dimensions associated with the negative valence of work, the retained items were rephrased in a more nuanced manner. Given their particularly high kurtosis coefficients, the team felt that the items were possibly written in terms that were too absolute, which made it difficult for the participants to agree with them. For example, the part of the item "(...) what I'm doing does not satisfy me" was replaced by "what I do at work does not give me much personal satisfaction." At the end of this process, this dimension consisted of 16 items equally distributed in each of the sub-dimensions.

\section{Dimension 3: purposes of work}

As initially designed, this dimension consisted of 40 items and seven sub-dimensions: (1) self-fulfillment and well-being; (2) social usefulness; (3) social contacts; (4) financial independence; (5) social identity and social status; (6) something to $d o$, and (7) occupational identity. After removing 12 items, the results supported the factor structure of the conceptual model (65.5\% of the explained variance). The selected items had factor loadings ranging from .46 to .86 and were distributed as follows: the first factor (five items) corresponded to the sub-dimension social usefulness with the exception of item 38, which conceptually belonged to the sub-dimension social identity and social status. The second factor (four items) referred to the sub-dimension financial independence. The third factor (four items) corresponded to the sub-dimension self-fulfillment and well-being. The fourth factor (four items) represented the sub-dimension social contacts. The fifth factor (four items) was consistent with the something to do sub-dimension. The sixth factor (four items) constituted the sub-dimension occupational identity. Finally, the seventh factor (three items) corresponded to the sub-dimension social identity and social status. At the end of the analysis, this dimension included seven sub-dimensions for a total of 28 items.

\footnotetext{
${ }^{5}$ In addition to these four sub-dimensions, there is also the sub-dimension "Ideal involvement profile in the different activities and roles in life." However, this sub-dimension was not included in the factor analyses.
} 


\section{Dimension 4: general expectations regarding working life}

Initially, this dimension consisted of 50 items and seven sub-dimensions: (1) development and use of knowledge and skills. Stimulating tasks; (2) usefulness of work; (3) moral rectitude; (4) work autonomy, diversity of tasks, and opportunities for career advancement; (5) interpersonal relations and support from the work environment; (6) recognition of skills and work accomplished, and (7) work organization and conditions. However, the results revealed a structure of six factors accounting for $55.4 \%$ of the variance. Based on previously established criteria, 20 items were excluded. The selected items showed a coefficient ranging from .41 to .84 . The first factor contained 11 items arising from three conceptually distinct sub-dimensions development and use of knowledge and skills. Stimulating tasks (items 39, 30, 25, 43), moral rectitude (items $47,41,33,14$ ), and work organization and conditions (items $31,45,26$ ). The second factor (three items) likewise corresponded to the subdimension work organization and conditions. The third factor (four items) referred to the sub-dimension interpersonal relations and support from the work environment. The fourth factor (four items) represented the sub-dimension recognition of skills and work accomplished. The fifth factor (four items) was related to the subdimension work autonomy, diversity of tasks, and opportunities for career advancement. Finally, the sixth factor (four items) constituted the sub-dimension usefulness of work.

As the factor analysis combined the items of two sub-dimensions moral rectitude and development and use of knowledge and skills. Stimulating tasks into a single factor, the definition of the sub-dimension moral rectitude was revised, starting from Morin's $(2006,2008)$ work, in order to accentuate the difference between the two sub-dimensions. In keeping with this approach, this sub-dimension was renamed ethical work environment, which now refers to the performance of tasks in an environment that values justice, fairness, and putting human beings first (e.g., "working in an environment in which workers are treated with respect"). Furthermore, the sub-dimension work organization and conditions, which initially comprised 12 items, was divided into two sub-dimensions so as to more clearly distinguish between expectations related to income and employment status versus those related to projects in spheres of life outside of work: workload and schedule and work-life balance and job security and income. At the end of this process, the dimension was reduced to 32 items that were divided into eight sub-dimensions.

\section{Dimension 5: obligations and duties of employers and society to workers}

This dimension was initially composed of 22 items and four sub-dimensions: (1) working conditions; (2) justice and fairness; (3) financial conditions and pay, and 4) satisfaction, respect, and recognition. The factor analysis revealed three factors (explaining 55.8\% of the variance) which, moreover, did not correspond to the theoretical model. The first factor comprised seven items (factor loadings from .55 to .75) associated with the two sub-dimensions, working conditions and satisfaction, respect, and recognition. The second factor was made up of four items (factor loadings from .55 to .73) linked to three sub-dimensions working conditions, justice and 
fairness, and financial conditions and pay. The third factor comprised two items (factor loadings of .56 and .71) from the financial conditions and pay sub-dimension. Considering these results, the whole dimension was substantially revised with a view to preparing the experimental questionnaire. Sub-dimensions were redefined and renamed, others were created, and five new items were added.

In its experimental version, this dimension is now composed of 18 items divided into six sub-dimensions (three items per sub-dimension): (1) job security and benefits; (2) support for well-being and work-life balance; (3) healthy work environment; (4) income; (5) occupational development support, and (6) participation support.

\section{Dimension 6: obligations and duties of workers to employers and society}

The dimension initially combined 15 items divided into three sub-dimensions: (1) commitment and responsibilities to employers and society; (2) contribution to the organization's success; and (3) work execution quality. First, the conducted analyses made it possible to remove six items. The items that were kept had factor loadings ranging from .49 to .91. The first factor combined the four items belonging to the sub-dimension work execution quality as well as an item (4) that was conceptually associated with the sub-dimension contribution to the organization's success. The second (three items) and third factors (two items) were made up of items initially associated with the sub-dimension commitment and responsibilities to employers and society. An examination of the factor structure led to a revision of the conceptualization and operationalization of this dimension. More specifically, this subdimension, commitment and responsibilities to employers and society, was split into two in order to conceptually distinguish the obligations and duties to society from those to the organization, thus giving: (1) commitment and responsibilities to society and (2) commitment and responsibilities to employers. Two items were also added. Finally, the items that initially belonged to the sub-dimension work execution quality were moved to the sub-dimension contribution to the organization's success and development, which made it possible to eliminate the sub-dimension work execution quality.

At the end of the process, this dimension comprised 11 items and consisted of three sub-dimensions: (1) commitment and responsibilities to society (three items); (2) commitment and responsibilities to employers (four items) and 3) contribution to the organisation's success and development (four items). It is worth noting that two new items were created.

\section{Dimension 7: representations of decent work}

Initially, this 22-item dimension consisted of four sub-dimensions: (1) income and working conditions; (2) justice; (3) dignity and respect; and (4) recognition and appreciation. The analyses led to the elimination of six items. Those that were retained had factor loadings ranging from .40 to .79 . The factor structure revealed four factors (accounting for $53.1 \%$ of the variance). The first factor (five items) corresponded to the sub-dimension dignity and respect, except for one item (20) which was conceptually associated with the sub-dimension justice. The second factor (four 
items) represented the sub-dimension recognition and appreciation. The third factor (four items) brought together the items of the sub-dimension income and working conditions, except for one item (4) which came from the sub-dimension justice. The fourth factor (three items) made up the sub-dimension justice. In the light of these results, item 4 which offers job security was moved to the sub-dimension income and working conditions and item 20 that respects the law was reworded as "in which the worker is treated without discrimination." At the end of the process, this dimension comprised 16 items divided equally among the four initial sub-dimensions.

\section{Correlation analysis results}

Overall, the correlations between the sub-dimensions of distinct dimensions were not high (see Table 3). Only three of them had values greater than or equal to $.5 .^{6}$ To be more precise, the sub-dimension primary importance and positive valence (dimension "relative centrality of work and work valence") was positively correlated with the sub-dimension existential value (dimension "absolute centrality of work") $(r=.7, p<.001)$. Two sub-dimensions referring to expectations regarding interpersonal relations and support from the work environment and work organization and conditions were respectively associated with two sub-dimensions belonging to the purposes of work social contacts $(r=.5, p<.001)$ and work autonomy $(r=.54$, $p<.001)$.

Examination of the correlation matrix between the sub-dimensions of the same dimension revealed several high correlations. For the first dimension, the "absolute centrality of work", the two sub-dimensions ideological value of work and existential value of work were correlated at $0.47(p<0.001)$. As for the dimension "relative centrality of work and work valence", the correlation between the two sub-dimensions secondary importance and negative valence and primary importance and negative valence was high $(r=.78, p<.001)$. This result was not surprising since, after conducting the factor analysis, these two sub-dimensions appeared to be merged into one single factor. As for the dimension "purposes of work," four sub-dimensions (social usefulness; occupational identity; social identity and, self-fulfillment) were closely related ( $r$ varying from .48 to $.61, p<.001$ ). As concerns the "general expectations regarding working life" dimension, the correlations observed for the sub-dimensions for general expectations ( $r$ ranging from .35 to $.65, p<.001$ ) and those for the coherence between expectation and reality ( $r$ varying from .47 to .72 , $p<.001)$ were moderate to high. Nonetheless, the sub-dimension work organisation and conditions belonging to the Reality coherence dimension were weaker $(r$ from .27 to $.33, p<.001$ ). The correlations between the three sub-dimensions of the dimension "obligations and duties of workers to their employers and society" varied from .49 to $.52(p<.001) .^{7}$ Finally, the correlations for the "representations of

\footnotetext{
${ }^{6}$ According to Cohen (1988), values of $0.1,0.3$, and 0.5 are respectively interpreted as low, medium, and high.

7 The "obligations and duties of employers and society to workers" dimension is not included in the correlation analyses, given the major changes made to it.
} 


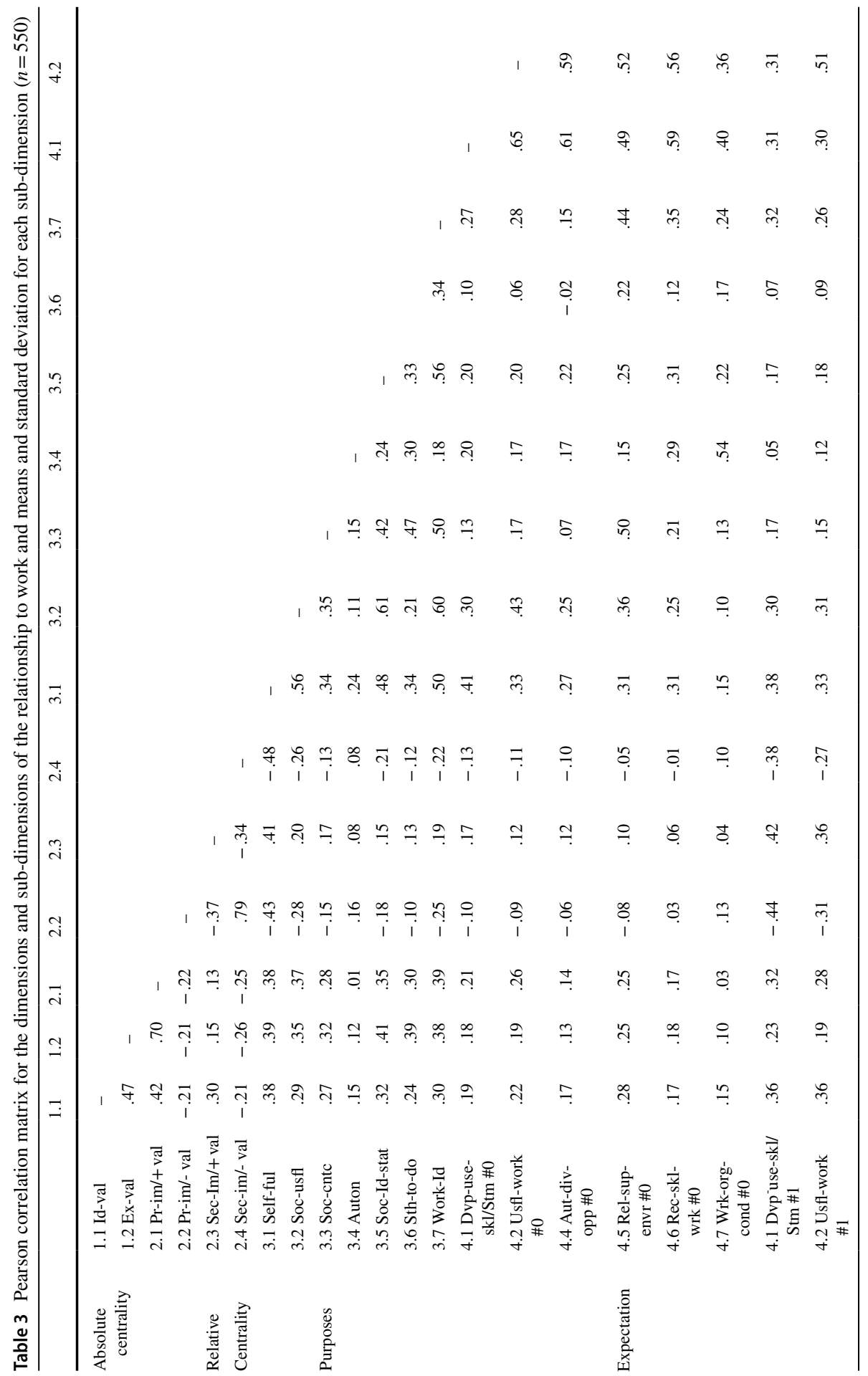




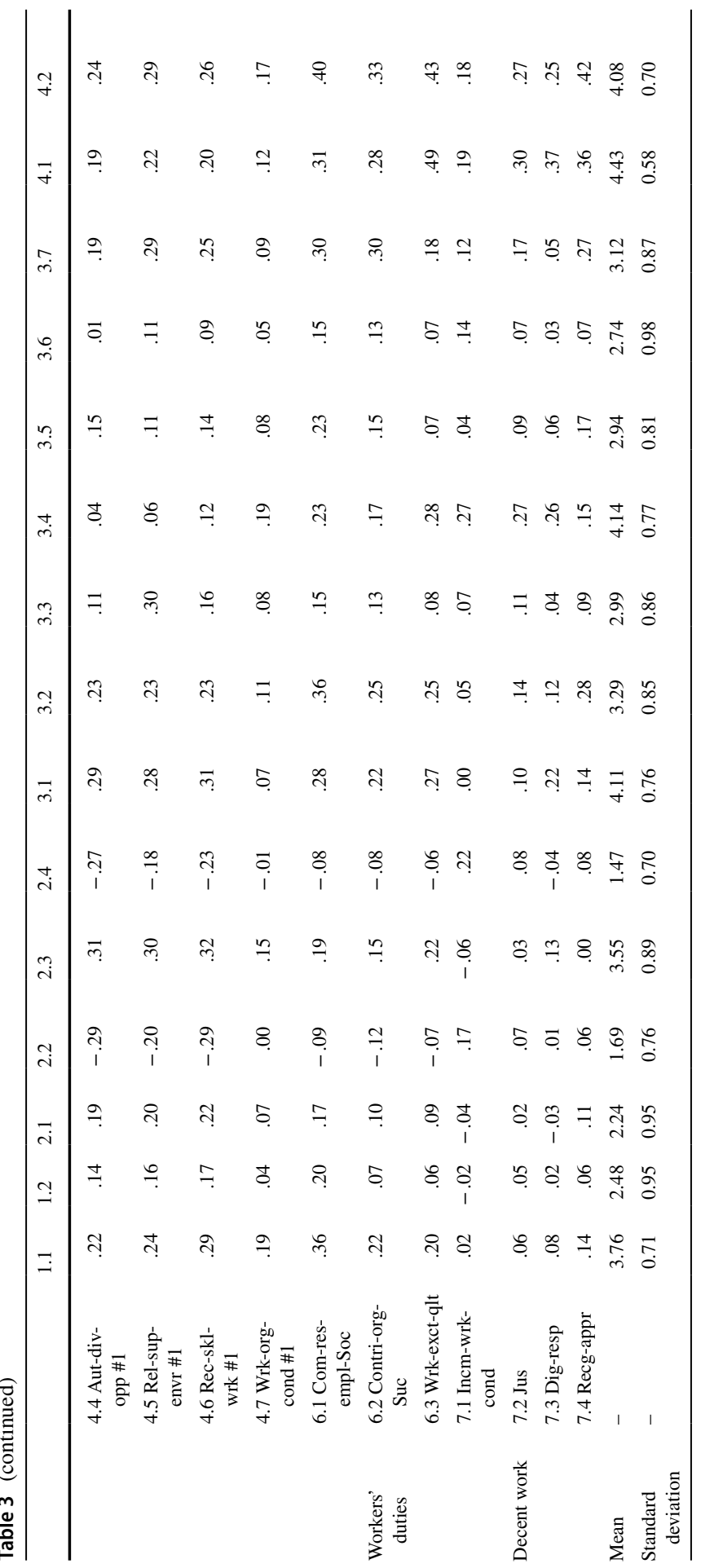




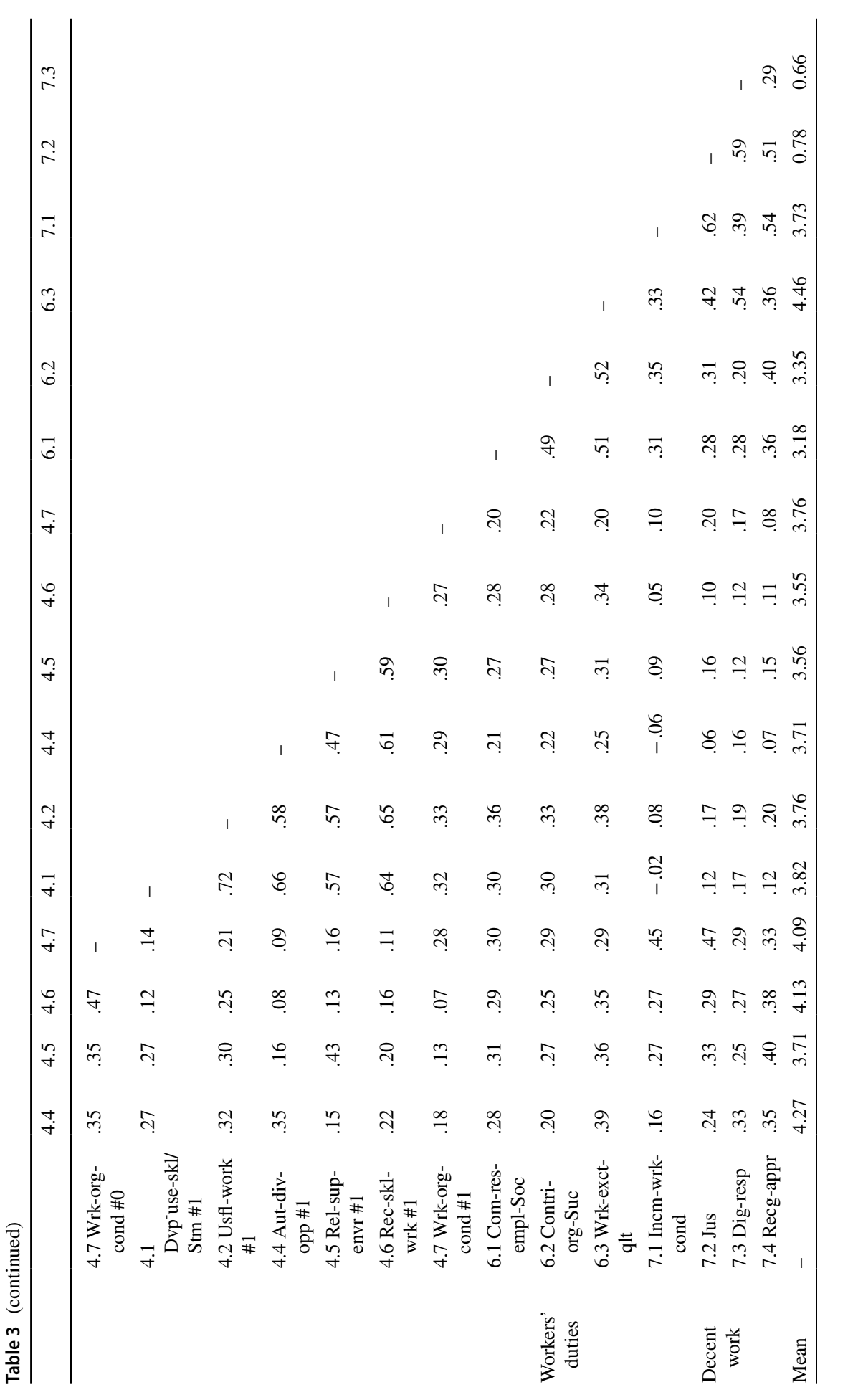




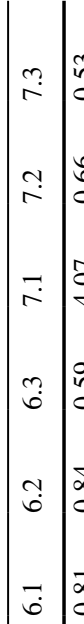

$$
\begin{aligned}
& \text { ษ }
\end{aligned}
$$

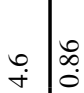

$$
\begin{aligned}
& \text { 约 } \\
& \text { 字 } \\
& \text { 4 } \\
& \stackrel{\circ}{\circ} \\
& =\quad \begin{array}{l}
- \\
+
\end{array} \\
& \text { 孚 } \\
& \text { 나융 } \\
& \text { ๆ } \\
& \stackrel{\forall}{\forall}
\end{aligned}
$$

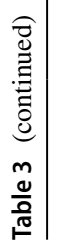

$$
\begin{aligned}
& \text { 告 }
\end{aligned}
$$


decent work" dimension went from low to high ( $r$ ranging from .29 to $.62, p<.001$ ). In short, as expected, the correlations between the dimensions of the questionnaire were generally weaker than those between sub-dimensions of the same dimension. These results provide reasonable support for the questionnaire's construct validity.

At the end of this analysis process, the experimental version of the questionnaire was comprised of 141 items, divided into seven dimensions and 35 sub-dimensions (Table 4).

\section{Discussion}

The goal of the present study was to develop and establish an initial validation of a multidimensional questionnaire for evaluating the relationship to work. The approach adopted here was based on four main stages. The first stage involved conceptually defining dimensions and sub-dimensions related to people's relationship to work, based on an in-depth review of the scientific literature and the results of our research carried out with workers over the last 20 years. The next stage consisted in operationalizing the dimensions and sub-dimensions. An initial bank of items was thus created which represented the definitions of pre-established concepts. In the third stage, this bank of items was submitted to a committee of experts from several countries in order to confirm the face and content validity of each of the questionnaire's dimensions and sub-dimensions. This operation reduced the number of items by almost a third (31.8\%). Items have been displayed randomly into in each of the seven dimensions that they were associated. It is this pre-experimental version of 201 items that was used to carry out the psychometric analyses. Finally, the aim of the fourth stage was to test the pre-experimental questionnaire with a population of over 500 workers and more than 500 students and to assess some of its psychometric properties in order to develop the experimental version of the questionnaire. ${ }^{8}$ This step eliminated 60 items $(29.8 \%)$ and reworked ten sub-dimensions to improve them conceptually and psychometrically.

\section{Structure and psychometric qualities}

With regard to the descriptive, factor, internal consistency, and correlation analyses, the questionnaire generally produced satisfactory psychometric qualities (Bentler, 1983; Cohen, 1988; Nunnally, 1978; Pett, et al., 2003). More precisely, the results of the factor analyses support the theoretical structure in two sub-dimensions of the dimension "absolute centrality of work" as well as that, in seven sub-dimensions, of the "purposes of work." With regard to the dimension "relative centrality of work and work valence," the factor analysis made it possible to identify two factors that corresponded to the two sub-dimensions theoretically associated with the positive valence of work. This result supports the relevance of combining the

\footnotetext{
8 The results of the exploratory factor analysis show the same factor structure in each dimension and sub-dimension for each sample (workers and students).
} 


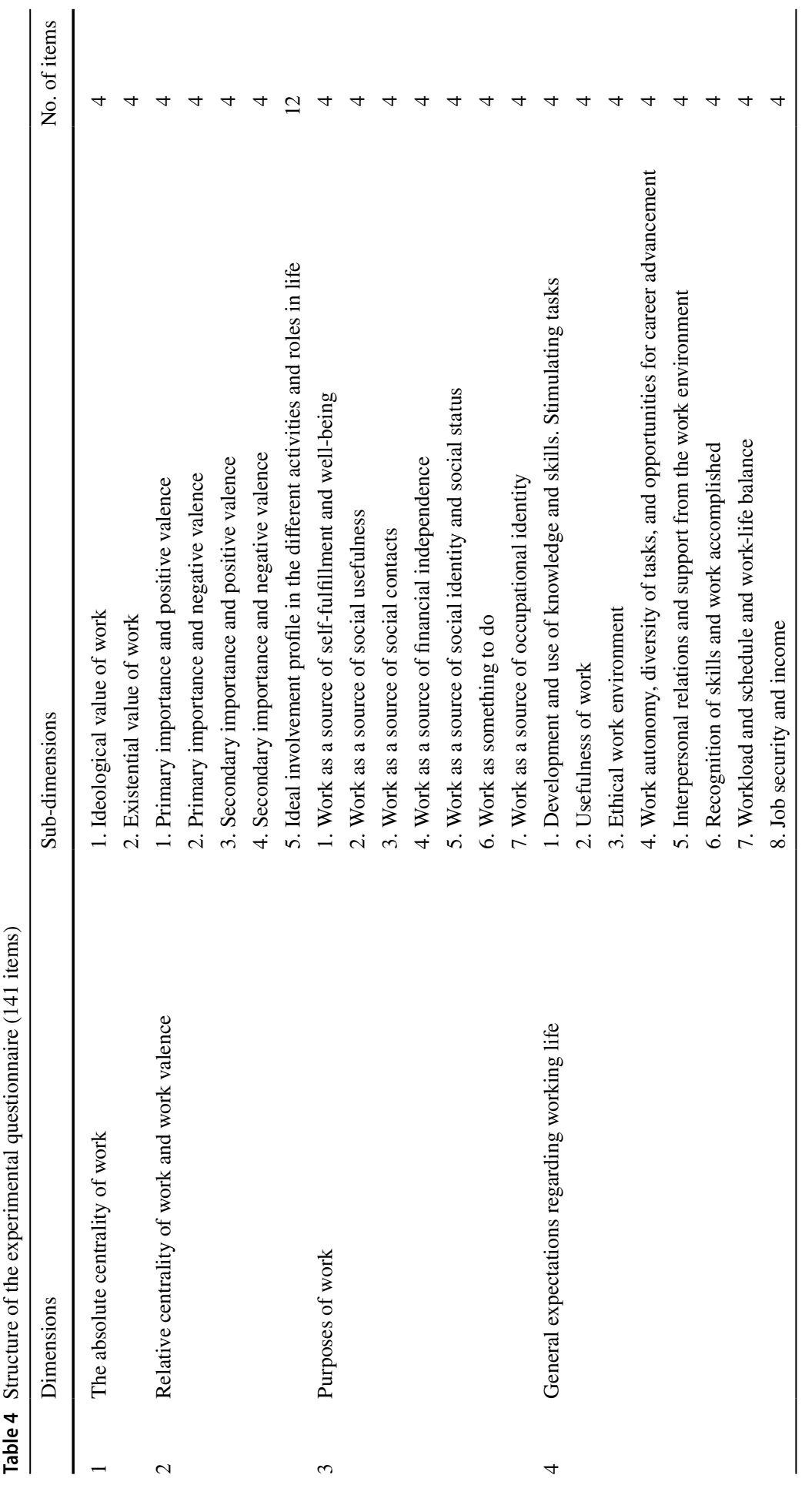




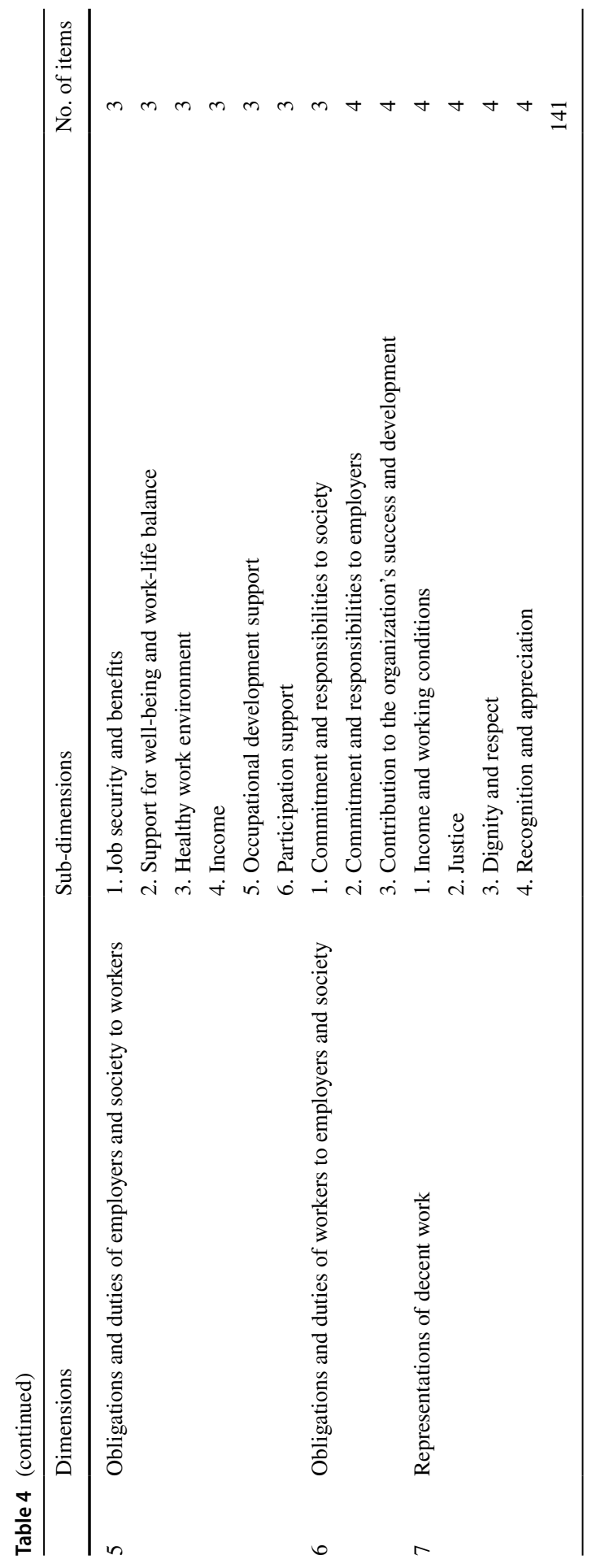


degree of importance accorded to work (primary and secondary) and the valence associated with it, and of creating two distinct sub-dimensions. However, the two sub-dimensions that were conceptually associated with the negative valence of work were grouped into a single factor. This result can be at least partially explained by the possibility of a bias related to the homogeneity of the sample used to pre-test the questionnaire. Coming from a university institution, the sample was primarily composed of highly skilled workers $(n=378 ; 78 \%)$ who were unionized, had permanent jobs, and generally enjoyed very good working conditions (e.g., pension plan, group health insurance, regular working hours, annual vacations). However, this dimension, particularly the positive or negative valence accorded to work, is particularly sensitive to the person's current work context (Guichard, 2013), which was particularly favourable for this sample. In fact, the percentages of workers who agreed with the items associated with the negative valence of work were very low and ranged from $0.5 \%$ to $12.7 \%$, with a mean of $7.5 \%(n=42)$. This low percentage makes it difficult to create two distinct factors corresponding to the two expected sub-dimensions. Future studies with the experimental version of the questionnaire and with diverse worker populations, some of which are particularly vulnerable, will perhaps make it easier to draw up a clearer factor structure for the sub-dimensions associated with the negative valence of work.

Five of the seven sub-dimensions corresponding to the theoretical model associated with the dimension "general expectations regarding working life" were identified in the factor analyses. However, the items of the sub-dimensions moral rectitude and development and use of knowledge and skills. Stimulating tasks were merged into a single factor. This result could be explained by the initial wording of the items, which may have led to some confusion among the participants and have made it difficult to distinguish between expectations related to the workplace and the values promoted there versus those more directly related to the actual carrying out of work or to occupational and personal development. Indeed, the way in which the original items were written, for both sub-dimensions, referred mainly to elements that primarily applied to the individual, such as, Agree with what I am doing (moral rectitude) and Carry out tasks that correspond to my abilities (development and use of knowledge and skills. Stimulating tasks). Consequently, to ensure that the subdimensions actually measured two distinct constructs, the sub-dimension (moral rectitude) was renamed and redefined. It refers, in the experimental version of the questionnaire, to people's expectations about working in a workplace that emphasizes justice, fairness, and putting human beings first.

Finally, the fifth and sixth dimensions, "obligations and duties of employers and society to workers" and "obligations and duties of workers to employers and society" required a deeper revision. The analyses of the dimensions did not arrive at the expected factor structure for the conceptual model. That being said, it is worth noting that these dimensions are less present in the scientific literature on the relationship to work; furthermore, the authors who have taken them into account, in particular the MOW team (1987), define each one as a unidimensional construct. This is, moreover, one of the reasons that motivated the choice of a large number of items. While the results tended to support the multidimensional nature of the dimensions, a relatively small number of the initially created sub-dimensions were clearly 
identified in the factor analyses. This was particularly the case for the dimension "obligations and duties of employers and society to workers". These results can be at least partially explained by the homogeneity of the study population. In fact, as previously mentioned, the participants came from the same institution, where the work conditions and culture were mostly the same, which made it difficult to obtain a wide range of viewpoints on aspects as normative as the relationship to work, which are mutual duties of employers and workers. Nonetheless, based on the results obtained here and in order to enhance the multidimensional composition of these two dimensions, the structure of both dimensions was reviewed and several items were reworded. Other research will make it possible to validate and adjust the modified structure. As for the second dimension "representations of decent work," the analyses support its theoretical structure with four sub-dimensions. Given the unique nature of this dimension, this result was, in our opinion, particularly promising.

Finally, the alpha coefficients were greater than .7 for all the dimensions and subdimensions except for the sub-dimension ideological value of work $(\alpha=0.54)$, which attests to the questionnaire's overall internal consistency. Moreover, the correlation analyses tended to support the seven-dimension structure of the relationship to work and to demonstrate the complexity of the construct.

\section{The questionnaire's contributions to the development of knowledge}

Although there were certain limitations to the results, they nonetheless made it possible to identify some potential contributions of the questionnaire to the development of knowledge about people's relationship and attachment to work in general and to their working lives. One of the originalities of this new tool was its use of numerous comments by people of all ages in quite diverse employment situations. Employing this particularly rich material has made it possible to add some nuances to the conceptualization of some already existing dimensions of the relationship to work (e.g., relative centrality of work and work valence) and to add sub-dimensions that are rarely addressed (e.g., ideological value of work) or absent from the scientific documentation on work (e.g., representations of decent work). The operationalization of the tool is also original in its nuanced expression of the different new realities that workers now face. Without pretending to be exhaustive, the whole set of items covers the main facets of the participants' relationship to work. Likewise, the questionnaire seems to capture fairly well the complexity of the multidimensional construct developed here.

More particularly, some of the questionnaire's contributions deserve a brief mention. With regard to the first dimension, "absolute centrality of work," the originality of its conceptualization is based on its consideration of two perceptions among people, namely the importance of work in human existence (ideological value) and the importance of work in their own lives (existential value). It is the latter that is more commonly addressed in meaning-of-work scales (e.g., Steger et al., 2012). This way of conceptualizing and operationalizing this dimension provides, we think, a relatively new, more complete understanding of people's perceptions of the centrality of work in their lives. At the operational level, this dimension is often measured with 
one or two items for which people must indicate, on a Likert scale, to what extent work is important for them; we, on the other hand, propose a more detailed and precise assessment.

The second dimension of the questionnaire, the "relative centrality of work and work valence," constitutes another potential contribution to our understanding and evaluation of people's relationship to work. Indeed, this novel association between the relative centrality of work and the valence accorded to it gives us a more precise appreciation of the many different ways people can invest in this sphere of life as compared to others. In the present day labour market and the various career paths that have arisen, the complexity of the current situation deserves close attention if we are to understand and measure it. Likewise, the creation of a sub-dimension, ideal involvement profile in the different activities and roles in life, constitutes another contribution to our understanding of people's relationship to work and its operationalization. This sub-dimension evaluates the extent to which one's level of involvement in work corresponds to what people actually want and, at the same time, gives a more precise interpretation of their relative involvement and its contribution to their relationship to work. The originality of this sub-dimension is also due to the fact that, by replacing the five usual spheres of life (work, family, leisure, community and religious involvement), 12 life activities are proposed which more faithfully reflect present-day life.

The conceptualization and operationalization of the third dimension, the "purposes of work", has enhanced, in some respects, the current evaluation by, on the one hand, adding categories that were not present in previously available tools (e.g., occupational identity) and by, on the other hand, proposing an improved operationalization (four items rather than one). Rooted in the workers' discourse, the created items should more precisely reflect the various purposes people pursue through work and the different ways of expressing these purposes.

As for the fourth dimension, the "general expectations regarding working life" its originality is, first of all, due to the fact that it specifically refers to working life rather than work, as is the case with most tools (e.g., Arnoux-Nicolas et al., 2016; Morin, 2006). It is also due to the creation of eight sub-dimensions inspired by research by MOW (1987), Morin and Forest (2007), and Warr (2008), but also drawn from workers' interviews, which are more likely to precisely express the latter's concrete expectations. Finally, the sub-dimension meaningful working life is another potential contribution of the questionnaire to our understanding and evaluation of expectations regarding working life. Indeed, the coherence or lack thereof between the expectations that workers expressed and their perceptions of what their working life actually brought them is, to the best of our knowledge, barely present in existing tools.

Dimensions 5, 6, and 7. "obligations and duties of employers and society to workers," "obligations and duties of workers to employers and society," and "representations of decent work" refer to normative and regulating representations of work. The contribution of dimensions 5 and 6 is more modest and is due primarily to the fact that distinct sub-dimensions were created and operationalized with a relatively large number of items, thus making room for certain nuances in the workers' perceptions of their obligations and duties. As for dimension 7, even though initiatives 
have been made to establish universal criteria so as to define and evaluate decent work (e.g., Anker et al., 2003; Burchell et al., 2014; Di Fabio \& Maree, 2016; Duffy et al., 2017), no scales have yet looked specifically at workers' subjective representations of what constitutes decent work, hence the interest and innovative nature of this contribution.

\section{Future research directions}

Overall, the different analyses conducted in this study allowed us to conduct a satisfactory initial validation of the questionnaire (201 items) and to develop an experimental version (141 items. This latter version is part of a much larger research program conducted with diverse populations of Canadian workers of all ages, French- and English-speaking, employed or not. There are four main objectives to the research program. The first objective, which is methodological in nature, consists, on the one hand, of confirming the experimental questionnaire's factor structure, its internal consistency, and the quality of its items; and, on the other, of verifying its convergent and discriminant validity (Campbell \& Fiske, 1959) as well as of documenting the temporal stability of its dimensions and sub-dimensions. The second objective is to employ the tool to analyze people's relationship to work based on socio-biographic variables, work context (e.g., unemployment, self-employment), people's lives (e.g., dependants), their satisfaction with their work situation, and the meaning that their past and projected career paths take on (Blustein, 2001, 2006, 2011; Chow et al., 2014; Crosnoe \& Elder, 2002; England \& Whitely, 1990; Guichard, 2013; Kenny et al., 2016; Peterson et al., 2005; Savickas et al., 2009). The third objective is to establish, based on a technological analysis (Borgen \& Barnett, 1987), specific profiles for the relationship to work that determine distinct ways of associating with and giving meaning to work and one's working life. The fourth and final objective of the research program consists in, on the one hand, evaluating the psychometric qualities of the questionnaire in a context outside of Canada (i.e., Switzerland; Italy) and, on the other hand, verifying the presence of intercultural differences regarding the relationship to work in order to eventually analyze the reasons for these differences.

\section{Implications for practice}

Guidance and career counsellors traditionally have to help young people, while they are still in school, to make choices that will prepare them for the new labour market (Fouad \& Bynner, 2008). They likewise have to accompany workers during transitions, radical changes in direction, and questions about one's identity at various, different stages of their lives (Anderson, Goodman, \& Schlossberg, 2012; Guichard, 2015; Kenny et al., 2016).

It would seem increasingly obvious that the relationship to work and its various dimensions are central and even essential data to be considered when helping people to make choices, identify personally significant projects, change direction, and integrate or reintegrate the labour market (Bernaud, Lhotellier, Sovet, Arnoux-Nicolas, 
\& Pelayo, 2015; Guichard, Bangali, Cohen-Scali, Pouyaud, \& Robinet, 2017; Savickas, 2009). To the best of our knowledge, however, there are no currently existing tools that can establish individual profiles for a person's relationship to work that are interpretable in various contexts (e.g., guidance, employability, rehabilitation, human resource management). The experimental version of the questionnaire developed here, once it has been subjected to other types of analyses, is likely to help to provide just such a tool, one that is useful for accompanying people-in particular during critical phases and turning points in their career path-by providing, for example, information on more stable, temporal aspects of their relationship to work as compared to those that are based more on current situations and contexts. Finally, the questionnaire and its possible diverse applications should be relevant for both students and workers, whatever their situation in the labour market. We think this constitutes a promising contribution not only to professional practice but also to research.

\section{Conclusion}

The present questionnaire on the relationship to work constitutes a promising and innovative tool for intervention and research. The relationship-to-work profiles that could eventually be identified with this tool are likely to provide valuable information to practitioners about the different aspects of their consultants' relationship to work and the concrete meaning they take on for these 21 st-century workers.

There are numerous research avenues that are opening up at this stage in the development of the questionnaire. It could, for example, be enhanced by validity studies conducted in other countries and in various cultural contexts. It would also benefit by being used in studies conducted with diverse populations confronted with particular contexts regarding work (e.g., completed studies) or life (e.g., immigration). The homogeneity of the population that served in the pre-experimentation constitutes, in effect, one of the main limitations of this study. In short, however, the questionnaire is innovative at the conceptual and operational level and its structure is already promising, despite the need for future studies to improve its robustness and psychometric properties.

\section{References}

Abbott, A. (2001). Time matters. On theory and method. Chicago, IL: University of Chicago Press.

Anderson, M. L., Goodman, J., \& Schlossberg, N. K. (2012). Counseling adults in transition: Linking Schlossberg's theory with practice in a diverse world (4th ed.). New York: Springer.

Anker, R., Chernyshev, I., Egger, P., Mehran, F., \& Ritter, J. A. (2003). Measuring decent work with statistical indicators. International Labour Review, 142(2), 147-178. https://doi.org/10.1111/j.1564913x.2003.tb00257.x.

Appay, B. (2001). Précarité, précarisation : réflexions épistémologiques. In M. J. P. Chauvin, F. Facy, \& V. Ringa (Eds.), Précarisation, risque et santé (pp. 5-28). Paris, France: INSERM.

Ardichvili, A. (2005). The meaning of working and professional development needs of employees in a post-communist country. International Journal of Cross Cultural Management, 5(1), 105-119. https://doi.org/10.1177/1470595805050826. 
Ardichvili, A. (2009). The relationship between meaning of working and socioeconomic transformations: The case of post-communist Russia. Advances in Developing Human Resources, 11(2), 218-234. https://doi.org/10.1177/1523422309332244.

Arnoux-Nicolas, C., Sovet, L., Lhotellier, L., Di Fabio, A., \& Bernaud, J.-L. (2016). Perceived work conditions and turnover intentions: The mediating role of meaning of work. Frontiers in Psychology, 7(May), 704. https://doi.org/10.3389/fpsyg.2016.00704.4.

Arvey, R. D., Harpaz, I., \& Liao, H. (2004). Work centrality and post-award work behavior of lottery winners. The Journal of Psychology: Interdisciplinary and Applied, 138(5), 404-420. https://doi. org/10.3200/jrlp.138.5.404-420.

Baker, N. A., Jacobs, K., \& Tickle-Degnen, L. (2003). A methodology for developing evidence about meaning in occupation: Exploring the meaning of working. OTJR: Occupation, Participation and Health, 23(2), 57-66. https://doi.org/10.1177/153944920302300203.

Bal, P. M., \& Kooij, D. (2010). The relations between work centrality, psychological contracts, and job attitudes: The influence of age. European Journal of Work and Organizational Psychology, 20(4), 497-523. https://doi.org/10.1080/13594321003669079.

Bentler, P. M. (1983). Some contributions to efficient statistics in structural models: Specification and estimation of moment structures. Psychometrika, 48(4), 493-517. https://doi.org/10.1007/bf022 93875.

Bernaud, J.-L., Lhotellier, L., Sovet, L., Arnoux-Nicolas, C., \& Pelayo, F. (2015). Psychologie de l'accompagnement: Concepts et outils pour construire le sens de la vie et du travail [Psychology coaching : Concepts and tools to develop meaning of life and of work]. Paris, France: Dunod.

Bessin, M., Bidart, C., \& Grossetti, M. (Eds.). (2010). Bifurcations. Les sciences sociales face aux ruptures et à l'événement [forks in the road: the social sciences approach to ruptures and events]. Paris, France: La Découverte.

Blustein, D. L. (2001). Extending the reach of vocational psychology. Toward an inclusive and integrative psychology of working. Journal of Vocational Behavior, 59(2), 171-182. https://doi.org/10.1006/ jvbe.2001.1823.

Blustein, D. L. (2006). The psychology of working: A new perspective for career development, counseling, and public policy. Mahwah, NJ: Erlbaum.

Blustein, D. L. (2011). A relational theory of working. Journal of Vocational Behavior, 79(1), 1-17. https ://doi.org/10.1016/j.jvb.2010.10.004.

Blustein, D. L., Olle, C., Connors-Kellgren, A., \& Diamonti, A. J. (2016). Decent work: A psychological perspective. Frontiers in Psychology, 7(407), 1-10. https://doi.org/10.3389/fpsyg.2016.00407.

Borchert, M., \& Landherr, G. (2009). The changing meanings of work in Germany. Advances in Developing Human Resources, 11(2), 204-217. https://doi.org/10.1177/1523422309333762.

Borgen, F. H., \& Barnett, D. C. (1987). Applying cluster analysis in counseling psychology research. Journal of Counseling Psychology, 34(4), 456-468. https://doi.org/10.1037/0022-0167.34.4.456.

Brief, A. P., \& Nord, W. R. (Eds.). (1990). Meaning of occupational work. Lexington, MA: Lexington Books.

Bujold, C., Fournier, F., \& Lachance, L. (2013). The meaning of work among nonstandard workers: A multifaceted reality. Canadian Journal of Counselling and Psychotherapy, 47(4), 480-499.

Burchell, B., Sehnbruch, K., Piasna, A., \& Agloni, N. (2014). The quality of employment and decent work: Definitions, methodologies, and ongoing debates. Cambridge Journal of Economics, 38(2), 459-477. https://doi.org/10.1093/cje/bet067.

Campbell, D. T., \& Fiske, D. W. (1959). Convergent and discriminant validation by the multitrait-multimethod matrix. Psychological Bulletin, 56(2), 81-105. https://doi.org/10.1037/h0046016.

Cardador, M. T. (2009). Banking on meaningful work: How organizations and recipients shape the meaning of helping others through work. Doctoral dissertation, University of Illinois.

Castel, R. (2006). La montée des incertitudes. Travail, protections, statut de l'individu [The Rise of Uncertainties. Work, protections, individual statute]. Paris, France: Seuil.

Chow, A., Krahn, H. J., \& Galambos, N. L. (2014). Developmental trajectories of work values and job entitlement beliefs in the transition to adulthood. Developmental Psychology, 50(4), 1102-1115. https://doi.org/10.1037/a0035185.

Coetsier, P., \& Claes, R. (1985). Centrality of work in the life spheres of individuals. In F. L. Denmark (Ed.). Social/ecological psychology and the psychology of women, XXIII International Congress of Psychology (Vol. 7, pp. 255-262). Amsterdam, Netherlands: North-Holland.

Cohen, J. (1988). Statistical power analysis for the behavioral sciences (2nd ed.). Hillsdale, NJ: Erlbaum. 
Consiglio, C., Cenciotti, R., Borgogni, L., Alessandri, G., \& Schwartz, S. H. (2016). The WVal: A new measure of work values. Journal of Career Assessment, 22, 1-18. https://doi.org/10.1177/10690 72716639691.

Cook, E. P. (1994). Role salience and multiple roles: A gender perspective. The Career Development Quarterly, 43(1), 85-95. https://doi.org/10.1002/j.2161-0045.1994.tb00849.x.

Coyle-Shapiro, J. A. M., \& Conway, N. (2004). The employment relationship through the lens of social exchange. In J. A. M. Coyle-Shapiro, L. M. Shore, M. S. Taylor, \& L. E. Tetrick (Eds.), The employment relationship: Examining psychological and contextual perspectives (pp. 5-28). Oxford, UK: Oxford University Press.

Coyle-Shapiro, J. A. M., \& Neuman, J. H. (2004). The psychological contract and individual differences: The role of exchange and creditor ideologies. Journal of Vocational Behavior, 64(1), 150-164. https://doi.org/10.1016/s0001-8791(03)00031-9.

Crosnoe, R., \& Elder, G. H., Jr. (2002). Successful adaptation in the later years: A life course approach to aging. Social Psychology Quarterly, 65(4), 309-328. https://doi.org/10.2307/3090105.

D'Amours, M. (2002). Diversification et fragmentation du travail. Le passage de l'emploi salarié typique à des formes de travail atypique chez les travailleurs de plus de 45 ans. Montréal, QC: INRSUrbanisation, Culture et Société.

Deltand, M., \& Kaddouri, M. (2014). Les individus face à l'épreuve des transitions biographiques [Individuals facing the trial of biographical transitions]. L'orientation scolaire et professionnelle, 43(4), 413-434. https://doi.org/10.4000/osp.4469.

DeVellis, R. F. (2003). Scale development: Theory and applications. Thousand Oaks, CA: Sage.

Di Fabio, A., \& Maree, J. G. (2016). Using a transdisciplinary interpretive lens to broaden reflections on alleviating poverty and promoting decent work. Frontiers in Psychology, 7, 503. https://doi. org/10.3389/fpsyg.2016.00503.

Di Ruggiero, E., Cohen, J. E., Cole, D. C., \& Forman, L. (2015). Competing conceptualizations of decent work at the intersection of health, social and economic discourses. Social Sciences \& Medicine, 133, 120-127. https://doi.org/10.1016/j.socscimed.2015.03.026.

Dik, B. J., Byrne, Z. S., \& Steger, M. F. (2013). Introduction: Toward an integrative science and practice of meaningful work. In B. Dik, Z. Byrne, \& M. Steger (Eds.), Purpose and meaning in the workplace (pp. 3-14). Washington, DC: American Psychological Association. https://doi. org/10.1037/14183-001.

Duffy, R. D. (2010). Spirituality, Religion, and Work Values. Journal of Psychology and Theology, 38(1), 52-61. https://doi.org/10.1177/009164711003800105.

Duffy, R. D., Allan, B. A., Blustein, D. B., England, J. W., Autin, K. L., Douglass, R. P., ... Santos, E. J. R. (2017). The Development and Initial Validation of the Decent Work Scale. Journal of Counseling Psychology, 64(2), 206-221. https://doi.org/10.1037/cou0000191.

Duffy, R. D., Blustein, D. L., Diemer, M. A., \& Autin, K. L. (2016). The psychology of working theory. Journal of Counseling Psychology, 63(2), 127-148. https://doi.org/10.1037/cou0000140.

Duffy, R. D., \& Sedlacek, W. E. (2007). The work values of first-year college students: Exploring group differences. The Career Development Quarterly, 55(4), 359-364. https://doi. org/10.1002/j.2161-0045.2007.tb00090.x.

Elder, G. H., Jr. (2009). Perspectives on the life course. In W. R. Heinz, J. Huinink, A. Weymann, \& L. E. Tetrick (Eds.), The life course reader. Individuals and societies across time (pp. 91-110). New York: Campus Verlag.

Elder, G. H., Jr., Kirkpatrick Johnson, M., \& Crosnoe, R. (2003). The emergence and development of life course theory. In J. T. Mortimer \& M. J. Shanahan (Eds.), Handbook of the Life Course (pp. 3-19). New York: Kluwer Academic Publishers.

Elizur, D. (1984). Facets of work values: A structural analysis of work outcomes. Journal of Applied Psychology, 69(3), 379-389. https://doi.org/10.1037/0021-9010.69.3.379.

England, G. W. (1991). The meaning of working in the USA: Recent changes. European Work and Organizational Psychologist, 1(2-3), 111-124. https://doi.org/10.1080/09602009108408516.

England, G. W., \& Whitely, W. T. (1990). Cross-national meanings of working. In A. P. Brief \& W. R. Nord (Eds.), Meanings of occupational work (pp. 65-106). Lexington, MA: Lexington Books.

Erbès-Seguin, S. (1991). La centralité de la catégorie travail [The central nature of the concept of work]. International Review of Community Development, 25, 103-107. https://doi.org/10.7202/10339 14 ar.

Fouad, N. A., \& Bynner, J. (2008). Work transitions. American Psychologist, 63(4), 241-251. https://doi. org/10.1037/0003-066x.63.4.241. 
Fournier, G., \& Bujold, C. (2005). Nonstandard career trajectories and their various forms. Journal of career assessment, 13(4), 415-438. https://doi.org/10.1177/1069072705277917.

Fournier, G., \& Croteau, L. (1997). Perceptions et attentes vis-à-vis du travail de jeunes diplômés. Psychologie du travail et des organisations, 3(3-4), 89-108.

Fournier, G., Gauthier, C., \& Zimmermann, H. (2012). Vers une définition du sentiment d'intégration professionnelle : le cas des travailleurs et des travailleuses de 45 ans et plus en situation d'instabilité d'emploi. Revue canadienne de counselling et de psychothérapie, 45(3), 280-305.

Fournier, G., Lachance, L., \& Bujold, C. (2009). Nonstandard career paths and profiles of commitment to life roles: A complex relation. Journal of Vocational Behavior, 74(3), 321-331. https://doi. org/10.1016/j.jvb.2009.02.001.

Fournier, G., Zimmermann, H., \& Gauthier, C. (2011). Instable career paths among workers 45 and over: Insight gained from long-term career trajectories. Journal of Aging Studies, 25(3), 233-242.

Fournier, G., Zimmermann, H., \& Gauthier, C. (2013). Travail atypique persistant chez des salariés de 45 ans et plus : du parcours d'intégration au parcours de précarisation socioprofessionnelle. In G. Fournier, B. Bourassa, \& C. Gauthier (Eds.), Les dynamiques d'insertion et d'intégration en emploi dans tous leurs états : évènements-clés et enjeux particuliers du cheminement professionnel (pp. 229-295). Québec, QC: Presses de 1'Université Laval.

Fournier, G., Zimmermann, H., Gauthier, C., \& Masdonati, J. (2014). L'expérience du chômage chez les travailleurs seniors : de la crise identitaire à la réflexion sur l'avenir. L'orientation scolaire et professionnelle, 43(3), 337-366. https://doi.org/10.4000/osp.4431.

Masdonati, J., Fournier, G., Pinault, M., \& Lahrizi, I. Z. (2016). The evolution of work values during the school-to-work transition: The case of young adults in the "missing middle". International Journal for Educational and Vocational Guidance, 16(2), 189-212. https://doi.org/10.1007/s1077 5-015-9300-z.

Gagné, M., Forest, J., Gilbert, M. H., Aubé, C., Morin, E., \& Malorni, A. (2010). The motivation at work scale: Validation evidence in two languages. Educational and Psychological Measurement, 70(4), 628-646. https://doi.org/10.1177/0013164409355698.

Gash, V. (2008). Bridge or trap? Temporary workers' transitions to unemployment and to the standard employment contract. European Sociological Review, 24(5), 651-668. https://doi.org/10.1093/esr/ jen027.

Gaudet, S. (2013). Comprendre les parcours de vie: une lecture au carrefour du singulier et du social. In S. Gaudet, N. Burlone, \& M. Lévesque (Eds.), Repenser la famille et ses transitions: repenser les politiques publiques. Québec, Canada: Les Presses de l'Université Laval.

Guerrero, S. (2005). La mesure du contrat psychologique dans un contexte de travail francophone. [Measurement of the Psychological Contract in a French Work Context]. Relations Industrielles, 60(1), 112-144. https://doi.org/10.7202/011541ar.

Guichard, J. (2004). Se faire soi [To make oneself self]. L'Orientation Scolaire et Professionnelle, 33(4), 499-534. https://doi.org/10.4000/osp.226.

Guichard, J. (2009). Self-constructing. Journal of Vocational Behavior, 75(3), 251-258. https://doi. org/10.1016/j.jvb.2009.03.004.

Guichard, J. (2013). Identifications, personnalisation et construction de soi. In Penser la socialisation en psychologie: Actualité de l'œuvre de Philippe Malrieu (pp. 205-219). Toulouse, France: ERES. https://doi.org/10.3917/eres.prete.2013.01.0205.

Guichard, J. (2015). From vocational guidance and career conuseling to Life Design dialogues. In L. Nota \& J. Rossier (Eds.), Handbook of the Life Design paradigm: From practice to theory and from theory to practice (pp. 11-25). Göttingen, Germany: Hogrefe.

Guichard, J., Bangali, M., Cohen-Scali, V., Pouyaud, J., \& Robinet, M. L. (2017). Concevoir et orienter sa vie: Les dialogues de conseil en Life design [Designing a life: the life design dialogues]. Paris, France: Éditions Qui-Plus-Est.

Guilbert, L., Bernaud, J.-L., Gouvernet, B., \& Rossier, J. (2016). Employability: Review and research prospects. International Journal for Educational Vocational Guidance, 16(1), 69-89. https://doi. org/10.1007/s10775-015-9288-4.

Guillaume, J. F. (2009). Les parcours de vie, entre aspirations individuelles et contraintes structurelles. Informations sociales, 156(6), 6-22.

Guillemard, A.-M. (2004). Recomposition des temps de la vie et reconfiguration de la protection sociale. In J. Gautié \& A.-M. Guillemard (Eds.), Recomposition des cycl0.8es de vie, réarticulation des temps de la vie, accompagnement des transitions et sécurisation des trajectoires : mutations et 
politiques (pp. 31-62), Rapport ACI Travail, Temps, Trajectoires et Transitions, Partie III. Paris, France: CEE.

Hansen, J. I. C., \& Leuty, M. E. (2012). Work values across generations. Journal of Career Assessment, 20(1), 34-52. https://doi.org/10.1177/1069072711417163.

Harding, S., \& Hikspoors, F. (1995). New work values. In theory and in practice. International Social Science Journal, 47, 441-455.

Harpaz, I., \& Fu, X. (1997). Work centrality in Germany, Israel, Japan, and the United States. CrossCultural Research, 31(3), 171-200. https://doi.org/10.1177/106939719703100301.

Harpaz, I., \& Fu, X. (2002). The structure of the meaning of work: A relative stability amidst change. Human Relations, 55(6), 639-667. https://doi.org/10.1177/0018726702556002.

Harpaz, I., Honig, B., \& Coetsier, P. (2002). A cross-cultural longitudinal analysis of the meaning of work and the socialization process of career starters. Journal of World Business, 37(4), 230-244. https://doi.org/10.1016/s1090-9516(02)00090-1.

Harpaz, I., \& Meshoulam, I. (2004). Differences in the meaning of work in Israel: Workers in high-tech versus traditional work industries. Journal of High Technology Management Research, 15(2), 163182. https://doi.org/10.1016/j.hitech.2004.003.001.

Hattrup, K., Ghorpade, J., \& Lackritz, J. R. (2007). Work group collectivism and the centrality of work a multinational investigation. Cross-Cultural Research, 41(3), 236-260. https://doi. org/10.1177/1069397107301975.

Heinz, W. R., Huinink, J., \& Weymann, A. (Eds.). (2009). The life course reader. Individuals and societies across time. Chicago, IL: The University of Chicago Press.

Hirschfeld, R. R., \& Feild, H. S. (2000). Work centrality and work alienation: Distinct aspects of a general commitment to work. Journal of Organizational Behavior, 21(7), 789-800. https://doi. org/10.1002/1099-1379(200011)21:7\%3c789:aid-job59\%3e3.0.co;2-w.

Hogan, T. P. (2007). Psychological Testing: A practical introduction (2nd ed.). Hoboken, NJ: Wiley.

ILO. (1990). Decent work. International labour conference 87th. Retrieved from, http://www.ilo.org/ public/libdoc/ilo/P/09605/09605(1999-87).pdf.

Isaksson, K., \& Johansson, G. (2000). Adaptation to continued work and early retirement following downsizing: Long-term effects and gender differences. Journal of Occupational and Organizational Psychology, 73(2), 241-256. https://doi.org/10.1348/096317900167001.

Johansson, U., \& Tham, K. (2006). The meaning of work after acquired brain injury. American Journal of Occupational Therapy, 60(1), 60-69. https://doi.org/10.5014/ajot.60.1.60.

Judge, T. A., Weiss, H. M., Kammeyer-Mueller, J. D., \& Hulin, C. L. (2017). Job attitudes, job satisfaction, and job affect: A century of continuity and of change. Journal of Applied Psychology, 102(3), 356-374. https://doi.org/10.1037/apl0000181.

Kalleberg, A. L. (2009). Precarious work, insecure workers: Employment relations in transition. American Sociological Review, 74(1), 1-22. https://doi.org/10.1177/00031224090740010.

Kanungo, R. N. (1982). Measurement of job and work involvement. Journal of Applied Psychology, 67(3), 341-349. https://doi.org/10.1037/0021-9010.67.3.341.

Kenny, M. E., Catraio, C., Bempechat, J., Minor, K., Olle, C., Blustein, D. L., \& Seltzer, J. (2016). Preparation for meaningful work and life: Urban high school youth's reflections on work-based learning 1 year post-graduation. Frontiers in Psychology, 7, 286. https://doi.org/10.3389/fpsyg.2016.00286.

Krumm, S., Grube, A., \& Hertel, G. (2013). The Munster work value measure. Journal of Managerial Psychology, 28(5), 532-560. https://doi.org/10.1108/jmp-07-2011-0023.

Kuchinke, K. P., Ardichvili, A., Borchert, M., Cornachione, E. B., Cseh, M., Kang, H. S., \& Zav'jalova, E. (2011). Work meaning among mid-level professional employees: A study of the importance of work centrality and extrinsic and intrinsic work goals in eight countries. Asia Pacific Journal of Human Resources, 49(3), 264-284. https://doi.org/10.1177/1038411111413217.

Kuchinke, K. P., \& Cornachione, E. B., Jr. (2010). The meaning of work and performance-focused work attitudes among midlevel managers in the United States and Brazil. Performance Improvement Quarterly, 13(4), 393-408. https://doi.org/10.1080/13678868.2010.501961.

Kuchinke, K. P., Cornachione, E. B., Jr., Oh, S. Y., \& Kang, H. (2010). All work and no play? The meaning of work and work stress of mid-level managers in the United States, Brazil, and Korea. Human Resource Development International: enhancing performance, learning, and integrity, 23(3), 57-76. https://doi.org/10.1002/piq.20090.

Kuchinke, K. P., Kang, H.-S., Oh, S. Y., \& Kang, H. (2008). The influence of work values on job and career satisfaction, and organizational commitment among Korean professional level employees. Asia Pacific Education Review, 9(4), 552-564. https://doi.org/10.1007/bf03025670. 
Lalive d'Épinay, C. (2005). De l'étude des personnes âgées au paradigme du parcours de vie. In D. Mercure (Ed.), L'analyse du social : Les modes d'explication (pp. 141-167). Québec, Canada: Les Presses de l'Université Laval.

Langley, R. (1995). The South African work importance study. In D. E. Super \& B. Sverko (Eds.), Life roles, values, and careers: International findings of the work importance study (pp. 188-203). San Francisco, CA: Jossey-Bass.

Lent, R. W. (2005). A social cognitive view of career development and counseling. In S. D. Brown \& R. W. Lent (Eds.), Career development and counseling: Putting theory and research to work (pp. 101-127). New York: Wiley.

Loriol, M. (2017). Le(s) rapport(s) des jeunes au travail, Rapports d'étude en ligne n²017-02, INJEP CNRS. 2017, p. 100.

Manfreda, K. L., Berzelak, J., Vehovar, V., Bosnjak, M., \& Haas, I. (2008). Web surveys versus other survey modes: A meta-analysis comparing response rates. International Journal of Market Research, 50(1), 79-104. https://doi.org/10.1177/147078530805000107.

Mannheim, B. (1975). A comparative study of work centrality, job rewards and satisfaction. Sociology of Work and Occupations, 2(1), 193-205. https://doi.org/10.1177/073088847500200104.

Mannheim, B. F., Chomsky, Y., \& Cohen, A. (1972). Work centrality, rewards and role strains of Israeli male occupational groups. Haifa, Israel: Center for the Study of Man at Work, Techmon Research and Development Foundation.

Manuti, A. (2006). Meaning of working, intrinsic motivation, labour market outlook and passivity in career planning. Bollettino di Psicologia Applicata, 248, 19-34.

Matthijs, P. B., \& Kooij, D. (2011). The relations between work centrality, psychological contracts, and job attitudes: The influence of age. European Journal of Work and Organizational Psychology, 20(4), 497-523. https://doi.org/10.1080/13594321003669079.

May, D. R., Gilson, R. L., \& Harter, L. M. (2004). The psychological conditions of meaningfulness, safety and availability and the engagement of the human spirit at work. Journal of Occupational and Organizational Psychology, 77, 11-37. https://doi.org/10.1348/096317904322915892.

McDonald, D. J., \& Makin, P. J. (2000). The psychological contract, organisational commitment and job satisfaction of temporary staff. Leadership \& Organization Development Journal, 21(2), 84-91. https://doi.org/10.1108/01437730010318174.

Méda, D. (2015). Le travail [Work]. Paris, France: Presses universitaires de France.

Méda, D., \& Vendramin, P. (2013). Réinventer le travail [Reinventing Work]. Paris, France: Presses universitaires de France.

Mercure, D. (2008). Stratégies d'entreprise et mondialisation : l'impartition flexible dans la dynamique organisationnelle des entreprises. Politiques publiques, action politique, territoire, Cahier de recherche, avril, p. 17

Mercure, D., \& Dahan-Seltzer, G. (2016). Le travail en Amérique du Nord. Sociologies pratiques, 3(3), 99-103. https://doi.org/10.3917/sopr.033.0095.

Mercure, D., \& Vultur, M. (2010). La signification du travail: nouveau modèle productif et ethos du travail au Québec [The meaning of work: New productive model and work ethos in Quebec]. Québec, Canada: Presses de l'Université Laval.

Merriman, K. K. (2017). Extrinsic work values and feedback: Contrary effects for performance and wellbeing. Human Relations, 70(3), 339-361. https://doi.org/10.1177/0018726716655391.

Mirvis, P. H., \& Hall, D. T. (1996). New organizational forms and the new career. In D. T. Hall (Ed.), The career is dead-long live the career: A relational approach to careers (pp. 72-101). San Francisco, CA: Jossey-Bass.

Morin, E. M. (2006). Donner un sens au travail [Making Work Meaningful]. Canada, documents HEC Montréal.

Morin, E. M. (2008). Sens du travail, santé mentale et engagement organisationnel [The meaning of work, mental health and organizational commitment]. Santé psychologique, Étude et recherche, IRSST, Rapport R-543.

Morin, E. M., \& Forest, J. (2007). Promouvoir la santé mentale au travail: donner un sens au travail [Promoting mental health at work: Giving meaning to work]. Gestion, 32, 31-36. https://doi. org/10.3917/riges.322.0031.

MOW International Research Team. (1987). The meaning of working. London, UK: Academic Press.

Niles, S. G., \& Goodnough, G. E. (1996). Life-role salience and values: A review of recent research. The Career Development Quarterly, 45(1), 65-86. https://doi.org/10.1002/j.2161-0045.1996.tb004 63.x. 
Nunnally, J. C. (1978). Psychometric theory (2nd ed.). New York: McGraw-Hill.

Nunnally, J. C., \& Bernstein, I. H. (1994). The assessment of reliability. In J. C. Nunnally \& I. Berstein (Eds.), Psychometric theory (3rd ed., pp. 248-292). New York, NY: McGraw Hill.

Palmade, J. (2003). L'incertitude comme norme [Uncertainty as a norm]. Paris, France: Presses Universitaires de France.

Parboteeah, P., \& Cullen, J. B. (2003). Social institutions and work centrality: Explorations beyond National culture. Organization Science, 14(2), 137-148. https://doi.org/10.1287/ orsc.14.2.137.14989.

Pattakos, A., \& Dundon, E. (2017). Discovering meaning through the lens of work. Journal of Constructivist Psychology, 30(1), 42-49. https://doi.org/10.1080/10720537.2015.1119084.

Patton, W., \& McMahon, M. (2006). Career development and systems theory: Connecting theory and practice. Rotterdam, Netherlands: Sense.

Paugam, S. (2000). Le salarié de la précarité. Les nouvelles formes de l'intégration professionnelle. Paris, France: PUF.

Paullay, I. M., Alliger, G. M., \& Stone-Romero, E. F. (1994). Construct validation of two instruments designed to measure job involvement and work centrality. Journal of Applied Psychology, 79(2), 224-228. https://doi.org/10.1037/0021-9010.79.2.224.

Peavy, R. V. (1993). Constructivist counseling: A prospectus. Guidance and Counseling, 9(2), 3-8.

Peavy, R. V. (2004). SocioDynamic counselling: A practical approach to meaning making. Chagrin Falls, $\mathrm{OH}$ : Taos Institute.

Peterson, G. W., Krumboltz, J. D., \& Garmon, J. (2005). Chaos out of order. New perspectives in Career Development in the Information Society. In J. Patrick \& D. L. Thompson (Eds.), Issues in career development (pp. 53-80). Greenwich, CT: Information Age Publishing.

Peterson, M. F., \& Ruiz-Quintanilla, S. A. (2003). Cultural socialization as a source of intrinsic work motivation. Group Organization Management, 28(2), 188-216. https://doi.org/10.1177/10596 01103028002002 .

Pett, M. A., Lackey, N. R., \& Sullivan, J. J. (2003). Making sense of factor analysis. The use of factor analysis for instrument development in health care research. Thousand Oaks, CA: Sage.

Pillon, T., \& Vatin, F. (2003). Traité de la sociologie du travail. Toulouse, France: Éditions Octares.

Pryor, R. G. L., \& Bright, J. E. (2003). The chaos theory of careers. Australian Journal of Career Development, 12(3), 12-20. https://doi.org/10.1177/103841620301200304.

Pryor, R. G. L., \& Davies, R. (1989). A comparison of conceptualizations of work centrality. Journal of Organizational Behavior, 10(3), 283-289. https://doi.org/10.1002/job.4030100308.

Puplampu, B. B. (2009). Deconstructing the current construction of MOW: "Meaning of work"What do we really mean? IFE Psychologia: An International Journal, 17(2), 79-105. https://doi. org/10.4314/ifep.v17i2.45304.

Ribeiro, M. A., Silva, F. F., \& Figueiredo, P. M. (2016). Discussing the notion of decent work: Senses of working for a group of Brazilian workers without college education. Frontiers in Psychology, 7 , 1-14. https://doi.org/10.3389/fpsyg.2016.00207.

Roberson, L. (1990). Functions of work meanings in organizations: Work meanings and work motivation. In A. P. Brief \& W. R. Nord (Eds.), Meaning of Occupational work (pp. 107-134). Lexington, MA: Lexington Books.

Robinson, J. P., Shaver, P. R., \& Wrightsman, L. S. (1991). Criteria for scale selection and evaluation. In J. P. Robinson, P. R. Shaver, \& L. S. Wrightsman (Eds.), Measures of personality and social psychological attitudes. San Diego, CA: Academic Press.

Ros, M., Schwartz, S. H., \& Surkiss, S. (1999). Basic individual values, work values, and the meaning of work. Applied Psychology: An International Review, 48(1), 49-71. https://doi. org/10.1111/j.1464-0597.1999.tb00048.x.

Rosso, B. D., Dekas, K. H., \& Wrzesniewski, A. (2010). On the meaning of work: A theoretical integration and review. Research in Organizational Behavior, 30, 91-127. https://doi.org/10.1016/j. riob.2010.09.001.

Rousseau, D. M. (1995). Psychological contracts in organizations: Understanding written and unwritten agreements. Thousand Oaks, CA: Sage Publications Inc.

Rubery, J. (2006). Shifting responsibility, changing labour market. In Shifting responsibilities conference report, Amsterdam, Amsterdam University Press.

Ruiz-Quintanilla, S. A. (1991). Introduction: The meaning of work. European Work and Organizational Psychologist, 1(2-3), 81-89. https://doi.org/10.1080/09602009108408514. 
Ruiz-Quintanilla, S. A., \& Wilpert, B. (1991). Are work meanings changing? European Work and Organizational Psychologist, 1(2-3), 91-109. https://doi.org/10.1080/09602009108408515.

Samuel, Y., \& Harpaz, I. (2004). Work and organization in Israeli: Studies of Israli Society. London, UK: Transaction.

Sapin, M., Spini, D., \& Widmer, E. (2007). Les parcours de vie: de l'adolescence au grand âge [The life-courses: from youth to old age]. Lausanne, Suisse: Presses polytechniques et universitaires romandes.

Saunders, S. L., \& Nedelec, B. (2014). What work means to people with work disability: A scoping review. Journal of Occupational Rehabilitation, 24(1), 100-110. https://doi.org/10.1007/s1092 6-013-9436-y.

Savickas, M. L. (2005). The theory and practice of career construction. In S. D. Brown \& R. W. Lent (Eds.), Career Development and Counseling (pp. 42-70). Hoboken, NJ: Wiley.

Savickas, M. L., Nota, L., Rossier, J., Dauwalder, J.-P., Duarte, M. E., Guichard, J., ... Bigeon, C. (2009). Life designing: A paradigm for career construction in the 21st century. Journal of Vocational Behavior, 75, 239-250. https://doi.org/10.1016/j.jvb.2009.04.004.

Sennett, R. (2000). Le travail sans qualités. Les conséquences humaines de la flexibilité. Paris, France: Albin Michel.

Settersten, R. A., Jr. (2003). Propositions and Controversies in Life-Course Scholarship. In R. A. Settersten Jr. (Ed.), Invitation to the life course. Toward new understandings of later life (pp. 15-45). Amityville, NY: Baywood Publishing Company.

Sharabi, M. (2011). The meaning of work among Jews and Arabs in Israel: The influence of ethnicity, ethnic conflict, and socio-economic variables. International Social Science Journal, 61(202), 501510. https://doi.org/10.1111/j.1468-2451.2011.01784.x.

Sharabi, M., \& Harpaz, I. (2010). Improving employees' work centrality improves organizational performance: Work events and work centrality relationships. Human Resource Development International, 13(4), 379-392. https://doi.org/10.1080/13678868.2010.501960.

Sharabi, M., \& Harpaz, I. (2011). Gender and the relative centrality of major life domains: Changes over the course of time. Community, Work \& Family, 14(1), 57-62. https://doi.org/10.1080/13668 803.2010.506033.

Sharabi, M., \& Harpaz, I. (2013). Changes of work values in changing economy: Perspectives of men and women. International Journal of Social Economics, 40(8), 692-706. https://doi.org/10.1108/ ijse-01-2012-0018.

Shea-Van Fossen, R. J., \& Vredenburgh, D. J. (2014). Exploring differences in work's meaning: An investigation of individual attributes associated with work orientations. Journal of Behavioral \& Applied Management, 15(2), 101-120.

Snir, R., \& Harpaz, I. (2005). Test-retest reliability of the relative work centrality measure. Psychological Reports, 97(2), 559-562. https://doi.org/10.2466/pr0.97.2.559-562.

Steger, M. F., Dik, B. J., \& Duffy, R. D. (2012). Measuring meaningful work: The work and meaning inventory (WAMI). Journal of Career Assessment, 20, 322-337. https://doi.org/10.1177/10690 72711436160.

Sullivan, S. E., \& Baruch, Y. (2009). Advances in career theory and research: A critical review and agenda for future exploration. Journal of Management, 35, 1542-1571. https://doi.org/10.1177/01492 06309350082.

Super, D. E. (1981). The relative importance of work. Bulletin-AIOSP, 37(81), 26-36.

Super, D. E., \& Sverko, B. (Eds.). (1995). Life roles, values, and careers: International findings of the Work Importance Study. San Francisco, CA: Jossey-Bass.

Sverko, B., Babarovic, T., \& Sverko, I. (2008). Assessment of values and role salience. In J. A. Athanasou \& R. Van Esbroeck (Eds.), International handbook of career guidance (pp. 539-563). Dordrecht, Netherlands: Springer.

Towler, A. J., \& Dipboye, R. L. (2003). Development of a learning style orientation measure. Organizational Research Methods, 6(2), 216-235. https://doi.org/10.1177/1094428103251572.

Turnley, W. H., \& Feldman, D. C. (1998). Psychological contract violations during corporate restructuring. Human Resource Management, 37(1), 71-83. https://doi.org/10.1002/(sici)1099-050x(19982 1) $37: 1 \% 3 \mathrm{c} 71$ :aid-hrm7\%3e3.0.co;2-s.

Turnley, W. H., \& Feldman, D. C. (1999). The impact of psychological contract violations on exit, voice, loyalty and neglect. Human Relations, 52(7), 895-922. https://doi.org/10.1177/001872679905200 703. 
Tziner, A., Ben-David, A., \& Sharoni, G. (2014). Attachment to work, job satisfaction and work centrality. Leadership \& Organization Development Journal, 35(6), 555-565. https://doi.org/10.1108/ lodj-08-2012-0102.

Valenduc, G., Vendramin, P., Marcello, P., \& Mariangela, P. (Eds.). (2009). Changing careers and trajectories. How individuals cope with organisational change and restructuring (Works Project). Louvain, Belgique: Université Catholique, Higher Institute of Labour Studies.

Vondracek, F. W., \& Porfeli, E. J. (2008). Social contexts for career guidance throughout the world: Developmental-contextual perspectives on career cross the lifespan. In J. A. Athanasou \& R. van Esbroeck (Eds.), International handbook of career guidance (pp. 209-225). New York: Springer Publishing.

Vultur, M., \& Bernier, J. (2014). Inégalités structurelles et inégalités fractales dans le contexte postfordiste du marché du travail. In D.-G. Tremblay \& M. Alberio (Eds.), Travail et Société: Une introduction à la sociologie du travail (pp. 371-394). Québec, Canada: Presses de l'Université du Québec.

Walsh, K., \& Gordon, J. R. (2008). Creating an individual work identity. Human Resource Management Review, 18(1), 46-61. https://doi.org/10.1016/j.hrmr.2007.09.001.

Warr, P. (2008). Work values: Some demographic and cultural correlates. Journal of Occupational and Organizational Psychology, 81, 751-775. https://doi.org/10.1348/096317907x263638.

Weiss, H. M. (2002). Deconstructing job satisfaction Separating evaluations, beliefs and affective experiences. Human Resource Management Review, 12(2), 173-194. https://doi.org/10.1016/s1053 -4822(02)00045-1.

Wils, T., Luncasu, M., \& Waxin, M. F. (2007). Développement et validation d'un modèle de structuration des valeurs au travail [Development and Validation of a Structural Model of Work Values]. Relations industrielles, 62(2), 305-332. https://doi.org/10.7202/016090ar.

World Value Survey. (2008). http://www.worldvaluessurvey.org/WVSContents.jsp.

Wrzesniewski, A., Dutton, J. E., \& Debebe, G. (2003). Interpersonal sensemaking and the meaning of work. Research in Organizational Behavior, 25, 93-135. https://doi.org/10.1016/s0191 $-3085(03) 25003-6$.

Young, R. A., \& Valach, L. (2004). The construction of career through goal-directed action. Journal of Vocational Behavior, 64(3), 499-504. https://doi.org/10.1016/j.jvb.2003.12.012.

Young, R. A., \& Valach, L. (2008). Action theory: An integrative paradigm for research and evaluation in career. In J. Athanasou \& R. van Esbroeck (Eds.), International handbook of career guidance (pp. 643-657). New York: Springer.

Publisher's Note Springer Nature remains neutral with regard to jurisdictional claims in published maps and institutional affiliations. 